Vol. 15 (2006): 423-443.

\title{
Effects of repeated phosphorus fertilisation on field crops in Finland 2. Sufficient phosphorus application rates on silty and sandy soils
}

\author{
Into Saarela \\ MTT Agrifood Research Finland, Plant Production Research, Soil and Plant Nutrition, \\ FI-31600 Jokioinen, Finland, e-mail: into.saarela@mtt.fi \\ Harri Huhta \\ MTT Agrifood Research Finland, Ecological Production, FI-50600 Mikkeli, Finland \\ Perttu Virkajärvi \\ MTT Agrifood Research Finland, North Savo Research Station, FI-71750 Maaninka, Finland
}

\begin{abstract}
In order to update fertilisation recommendations for Finnish silty and sandy soils, the effects of repeated phosphorus (P) fertilisation on the yields of cereals, grasses and other crops were measured at ten sites for 9 to 18 years. Results of some earlier studies were also used in examining the relationships of the yield responses to applied $\mathrm{P}$ and to the soil test values measured by the Finnish ammonium acetate method $\left(\mathrm{P}_{\mathrm{Ac}}\right)$. Significant effects of $\mathrm{P}$ fertilisation were observed at all sites that had low or medium $\mathrm{P}_{\mathrm{Ac}}$ values; in the case of potatoes, even at sites with fairly high values. The mean relative yield without applied $\mathrm{P}$ divided by yield with 60 or $45 \mathrm{~kg} \mathrm{Pha}^{-1}$ of the ten sites was $81 \%$ (mean $\mathrm{P}_{\mathrm{Ac}} 11.6 \mathrm{mg} \mathrm{dm}^{-3}$ ) varying from $55 \%$ at the $\mathrm{P}_{\mathrm{Ac}}$ value of $4.7 \mathrm{mg} \mathrm{dm}^{-3}$ to $100 \%$ at the highest $\mathrm{P}_{\mathrm{Ac}}$ values. In order to achieve a relative yield of $97 \%$, which is considered the optimum for cereals and leys, the required mean annual application of $\mathrm{P}$ in the later parts of the experiments was $25 \mathrm{~kg} \mathrm{ha}^{-1}$ (variation $0-42 \mathrm{~kg} \mathrm{ha}^{-1}$ ). On the six soils that had low or medium $\mathrm{P}_{\mathrm{Ac}}$ values (4.5-9.1 mg dm${ }^{-3}$, mean $8.0 \mathrm{mg} \mathrm{dm}^{-3}$ ), relative yield was $97 \%$ at the $\mathrm{P}$ application rate of $35 \mathrm{~kg} \mathrm{ha}^{-1}$ (variation 22-42 $\mathrm{kg} \mathrm{ha}^{-1}$ ), while $11 \mathrm{~kg} \mathrm{P} \mathrm{ha}^{-1}$ (variation $0-25 \mathrm{~kg} \mathrm{ha}^{-1}$ ) sufficed on the four soils that had higher $\mathrm{P}_{\mathrm{Ac}}$ values (mean $20.8 \mathrm{mg} \mathrm{dm}^{-3}$, variation $11.7-35.2 \mathrm{mg} \mathrm{dm}^{-3}$ ). Reasons for the poor availability of $\mathrm{P}$ in silty and sandy soils were discussed.
\end{abstract}

Key-words: acid ammonium acetate method, soil test $\mathrm{P}$, soil phosphorus, sufficient $\mathrm{P}$ fertilisation 
Saarela, I. et al. Effects of repeated phosphorus fertilisation on field crops: silty and sandy soils

\section{Introduction}

Almost all Finnish soils have been deficient in available phosphorus (P) (Salonen and Tainio 1957), but the general use of $P$ fertilisers since the 1940s has markedly improved the P status of cultivated soils. After the rapid build-up of soil P reserves and the introduction of the placement fertilisation technique in the 1960s and early 1970s, earlier field experiments were no longer considered adequate for estimating $\mathrm{P}$ fertilisation needs. To update $\mathrm{P}$ fertiliser recommendations for the enriched soils and the current cultivation practices, field experiments with different rates of repeated $P$ fertilisation were carried out at twenty-four sites, of which ten were performed on silty and sandy soils.

Earlier papers from the project include a report on the original results and summaries in Finnish (Saarela et al. 1995), a review of earlier studies on $\mathrm{P}$ in Finnish soils (Saarela 2002), studies on the P status of the twenty-four experimental soils of this project (Saarela et al. 2003), changes of soil-test $P$ values in relation to $P$ balance (Saarela et al. 2004) and the yield results from eight clay and loam soils (Saarela et al. 2006). One clay soil and one loam soil were assessed for arbuscular mycorrhiza (Kahiluoto et al. 2001). Silty and sandy soils are the dominating soil types in the central, eastern and northern parts of Finland and cover more than one million hectares or about $50 \%$ of the total cultivated land area of Finland. Silty and sandy soils are mainly used for grain and grass production, while a small surface is devoted to the cultivation of potatoes, sugar beets and oilseed rape.

Previous studies suggest that the silty and sandy soils in the Finnish inland require more $\mathrm{P}$ for efficient plant production than the amount required in the coastal clay and loam soils (Salonen and Tainio 1957, Syvälahti 1970, Saarela et al. 1995). The grain yields of oats obtained with and without applied P in short-term studies on 368 clearings (Syvälahti 1970) showed the differences in the supply of native $\mathrm{P}$ from three main soil types in seven regions. The yields were recalculated for two areas of which the southern and western area
(SW) included the regions of Sata-Häme, Pirkanmaa, Päijät-Häme, Southern Karelia and Southern Ostrobothnia and the southern coastal regions, whereas the central, eastern and northern area (CEN) represented the other parts of Finland. The results (Fig. 1) show that the southern and western clay soils produced fairly good yields without any $P$ fertilisation and that the effect of $P$ fertilisation was small. The relative control yield obtained with NK fertilisation, in per cent of the yield with NPK fertilisation, was $92 \%$. Even this group certainly included glacial silty clay loams which later have supplied less P to crops than the coastal glacial and Litorina soils with the same soil test $\mathrm{P}$ value measured by the Finnish acetate method, $\mathrm{P}_{\mathrm{Ac}}$ (Saarela et al. 1995, 2006). The generally low $\mathrm{P}_{\mathrm{Ac}}$ values of clay soils and the higher values of coarser soils measured in early studies (Vuorinen 1952, Kurki 1982) did not correctly predict the biological availability of $\mathrm{P}$ in various soil types.

In the inland regions of Finland (CEN) the role of $\mathrm{P}$ fertilisation was much more essential in a comparable soil type, which actually means silt loam or silty clay loam soils, in which the RCY was $79 \%$ (Fig. 1). In the hilly inland the clay fraction may be coarser and the soils appear siltier than the coastal clays with the same percentage of clay (Sippola 1974). The unstable silty soils are easily compacted and dry to substantial depths through evaporation, and plants tend to root weakly in them. Silty soils are therefore sensitive to drought, which further restricts the supply of $\mathrm{P}$ to crops.

On coarser mineral soils the yield increases were similar for both areas, but the smaller yields from the CEN area resulted in lower relative control yield (RCY) values, $77 \%$ vs. $83 \%$ in the SW area. The mean amount of broadcast and incorporated $\mathrm{P}$, less than $20 \mathrm{~kg} \mathrm{ha}^{-1}$ (Syvälahti 1970), did not suffice for large yields in initially deficient soils. According to the responses of grain yields to increasing rates of $\mathrm{P}$ fertiliser (Sippola 1980, Saarela et al. 1995), a sufficient amount of P fertiliser would have doubled the yield increases. Replacing the $\mathrm{P}$ removed $\left(6 \mathrm{~kg} \mathrm{ha}^{-1}\right)$ in the modest grain yields would have caused at least fifty per cent smaller responses and ten per cent smaller yields. Similar results from peat soils in the south- 
Vol. 15 (2006): 423-443.

Fig. 1. Effects of $\mathrm{P}$ fertilisation on the grain yields of oats grown on newly cleared soils consisting of three different soil types in two regions of Finland. Original results by Syvälahti (1970), recalculated for this study.

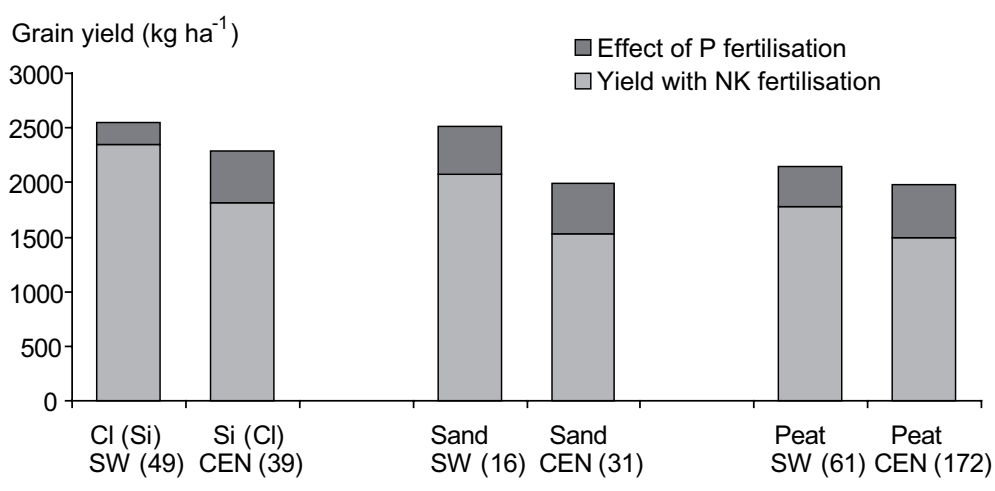

Soil type $(\mathrm{Cl}=$ clay, $\mathrm{Si}=$ silt) and region (number of experiments) (SW = southern, western, CEN = central, eastern, northern) ern and northern areas suggest that the role of climate is not very important.

In agreement with the short-term studies reviewed above, the yield responses to repeated $\mathrm{P}$ fertilisation have been larger on sandy soils than on clay and loam soils (Salonen and Tainio 1957). The large P fertilisation needs of Finnish silty soils preliminary reported earlier (Saarela et al. 1995) could not be expected from previous studies. The good efficiency of $\mathrm{P}$ fertilisation on sandy soils in Lithuania (Vaishvila et al. 2000) suggested that coarse-textured soils might be deficient in P. According to the model calculations by van Noordwijk et al. (1990), the physical and chemical properties of coarse-textured soils are less favourable for $\mathrm{P}$ uptake, so that higher concentrations of water extractable $\mathrm{P}$ are required in coarse-textured soils than in fine-textured soils.

In order to update fertilisation recommendations for Finnish silty and sandy soils, the effects of annual P fertilisation on the yields of cereals, grasses and other crops were measured at ten sites for 9 to 18 years. The main purpose was to define the amounts of $\mathrm{P}$ required to maintain a sufficient supply of P from the soil (Saarela et al. 2004) to produce optimum yields in the long-term (Saarela et al. 1995). Although the study was focused on certain types of mineral soils, the ten sites did not represent all possible combinations of soil type and $\mathrm{P}$ supply from these soils. To improve the reliability and applicability of the results, the yield effects of repeated $\mathrm{P}$ fertilisation obtained from the ten sites of this study were supplemented with the results of some earlier studies of sandy and silty soils.

\section{Yield and soil data from earlier studies}

The results of field studies with repeated $\mathrm{P}$ fertilisation compiled in Table 1 include data from six experiments run for 6-33 years and from twelve shorter field studies. Extensively cultivated grasses and cereals were the main crops in the older projects not specified in Table 1. Several rates of $\mathrm{P}$ fertilisation were compared at most of the sites, but the response curves of the short-term experiments were generally too flat for an exact definition of the sufficient rate. The relative yield of $97 \%$ of the crop amount produced with large amounts of $\mathrm{P}$ was considered the optimum. The largest $\mathrm{P}$ rates (about $35 \mathrm{~kg} \mathrm{ha}^{-1}$ ) used in two $\mathrm{P}$ deficient soils (Table 1, ref. 1) did not suffice to raise their modest yields to the maximum level of the response curve.

The absolute yield responses were larger in the recent short-term studies in intensively cropped 
leys. The effect of $\mathrm{P}$ fertilisation was generally between 250 and 800 feed units per hectare corresponding to $400-1300 \mathrm{~kg} \mathrm{ha}^{-1}$ of grass dry matter (Table 1, ref. 5). The supply of $\mathrm{P}$ to crops appeared to be efficiently improved by periodical manure application on a hill moraine in Tohmajärvi (Table 1, ref. 2). The tuber yield responses of potato to large amounts of $\mathrm{P}$ fertiliser were substantial on a fine sand soil in Mikkeli and a silt loam soil in Laukaa (Table 1, ref. 4). Fifty per cent smaller rates of $\mathrm{P}$ did not suffice for maximum yields (Varis 1972). The high $P$ needs of potato were further shown by the small but statistically significant effect measured on a sandy loam soil in Jokioinen with $\mathrm{P}_{\mathrm{Ac}}$ values as high as $36.5 \mathrm{mg} \mathrm{dm}^{-3}$ (Table 1 , ref. 6).

The higher biological requirement and economic optimum of $\mathrm{P}$ fertilisation of some other crops than cereals was recently established in Germany by Munk et al. (2005), who found as high economically optimal rates of annual $\mathrm{P}$ fertilisation as $90 \mathrm{~kg} \mathrm{P} \mathrm{ha}^{-1}$ for soils that had low STP values. In the sites where only cereals were grown, no more than $35 \mathrm{P} \mathrm{ha}^{-1}$ (as the sum of fertiliser and organic P) was required for optimum yields. The optimum range of soil test $\mathrm{P}$ value $(\mathrm{CAL}$, calcium ammonium lactate method) was as high as $80-100$ mg $\mathrm{P} \mathrm{kg}^{-1}$, which corresponds to a $\mathrm{P}_{\mathrm{w}}$ range of about 18-22 $\mathrm{mg} \mathrm{kg}^{-1}$ (Schachtschabel 1973) and is higher than typical in Finnish soils (Saarela et al. 2003). Most of the soils assessed by Munk et al. (2005) were loams and the clay percentages measured for 36 of the 43 soils ranged from 8 to $35 \%$.

\section{Material and methods}

\section{Soil characteristics at experimental sites}

The ten silty and sandy soils of this study (Table 2) included five types of mineral soil: 1) glacial silty clay loams in hilly landscape (sites 9 and 16, Finnish silty clay, according to Elonen 1971), visually classified as clayey silt; 2) silt loams in flat river valleys with high organic matter content (sites 12 and 13, the latter sulfic and strongly acid, Finnish silt rich in organic matter; 3 ) silt loams (sites 11 and 17, Finnish silty fine sand and silt, respectively); 4) loamy sands with more than 50\% $<0.06 \mathrm{~mm}$ in diameter (sites 10 and 15, Finnish finer fine sand); and 5) loamy sands with more than 50\% $>0.06 \mathrm{~mm}$ (sites 14 and 18, Finnish coarser fine sand).

Soil 11 was tentatively classed as Haplic/Gleyic Podzol, all others as Regosols according to the FAO system (Saarela et al. 2003). Only soil 14 was well-sorted (2\% clay) and really coarse-textured (78\% sand $>0.06 \mathrm{~mm}$ ). All the other soils had at least $5 \%$ clay, and their main particle-size fraction was finer than $0.06 \mathrm{~mm}$ in diameter, except the loamy sand 18 , which had $10 \%$ clay. The wellsorted sandy soils and corresponding sandy tills, in which the main fraction is coarser than $0.06 \mathrm{~mm}$, are found on $30 \%$ of the cultivated area of Finland (Kähäri et al. 1987). The coarse-textured soils which were underrepresented among the ten sites were supplemented by two short-term field experiments in Muhos (Table 1, ref. 5) on soils containing $2 \%$ clay and $86 \%$ particles $>0.06 \mathrm{~mm}$ in diameter (Saarela and Elonen 1982).

The properties of the ten silty and sandy soils measured from the initial samples (Saarela et al. 2003) are reviewed in Table 2. Some soil test $P$ values that were determined in an international comparison of chemical methods (Saarela et al. 1996) are also presented. The ammonium lactate $P$ values (Egnér et al. 1960) are medium (41-80) or high according to Swedish calibration, as are the calcium lactate $\mathrm{P}$ values according to Estonian calibration (medium $=31-61$ ). The resin $\mathrm{P}$ values (van Raij 1998) are high or very high according to Brazilian ratings (high $=41-80$ ). The $\mathrm{CaCl}_{2}$ method introduced by Houba et al. (1990) extracted little $\mathrm{P}$ from most Finnish mineral soils, indicating a low content of dissolved $\mathrm{P}$ in soil solution, or a low intensity of soil $\mathrm{P}$, in agreement with $\mathrm{P}_{\mathrm{w}}$. However, the concentrations of $\mathrm{P}$ extracted from the soils which had high initial $\mathrm{P}$ values (17 and 18) increased most sharply by the $\mathrm{CaCl}_{2}$ method.

In accordance with the more quantitative character of the Olsen method (Saarela et al. 2003), some of the values measured by a modified proce- 
Vol. 15 (2006): 423-443.

Table 1. Effects of annual P fertilisation, periodical manure application (Tohmajärvi) and initial liming (Laukaa) on crop yields in earlier studies conducted on silty and sandy soils in Finland, with the corresponding relative control yields. The rate of annually repeated $\mathrm{P}$ fertilisation and corresponding soil test $\mathrm{P}$ value required to achieve the relative yield (RY) of $97 \%$ are given for four soils.

\begin{tabular}{|c|c|c|c|c|c|c|c|c|c|c|c|}
\hline $\begin{array}{l}\text { Location } \\
\text { Latitude (N) }\end{array}$ & Soil type & $\begin{array}{l}\text { Years } \\
\text { (Soil test) }\end{array}$ & $\begin{array}{l}\text { Basic } \\
\text { treatment }\end{array}$ & $\begin{array}{c}\mathrm{P} \mathrm{kg} \mathrm{ha}^{-1} \mathrm{a}^{-1} \\
\text { NPK }\end{array}$ & $\begin{array}{l}\text { Yield }^{1)} \\
\text { NPK }\end{array}$ & $\begin{array}{c}\mathrm{RCY}^{2)} \\
\mathrm{NK}\end{array}$ & $\begin{array}{c}\text { Soil } \mathrm{P}_{\mathrm{Ac}}{ }^{3)} \\
\mathrm{NK}\end{array}$ & $\begin{array}{l}\text { Soil } \\
\mathrm{pH}_{\mathrm{w}}\end{array}$ & \multicolumn{2}{|c|}{$\begin{array}{l}\text { RY } 97 \% \text { at } \\
P \text { rate } P_{A c}\end{array}$} & Ref. ${ }^{4)}$ \\
\hline Hartola & Fine sand & $1936-54$ & No & 36 & 2380 & 78 & 3.5 & 5.7 & $>36$ & $>10.9$ & 1 \\
\hline 61.40 & $8.5 \% \mathrm{OM}$ & (1953) & & & & & & & & & \\
\hline $\begin{array}{l}\text { Pihtipudas } \\
63.20\end{array}$ & Sandy till & $\begin{array}{l}1932-54 \\
(1953)\end{array}$ & No & 34 & 2290 & 75 & 1.3 & 6.3 & $>34$ & $>10.0$ & 1 \\
\hline $\begin{array}{l}\text { Pihtipudas } \\
63.30\end{array}$ & Sandy till & $\begin{array}{l}1933-54 \\
(1953)\end{array}$ & No & 36 & 3080 & 89 & 11.7 & 5.8 & 12 & 18.0 & 1 \\
\hline $\begin{array}{l}\text { Lohtaja } \\
64.00\end{array}$ & Fine sand & $\begin{array}{l}1948-53 \\
(1953)\end{array}$ & No & 48 & 3020 & 98 & 19.1 & 5.3 & 0 & 19.1 & 1 \\
\hline Tohmajärvi & Sandy till & 1949-65 & No & 22 & 2610 & 87 & 3.8 & 5.6 & & & 2 \\
\hline 62.10 & & (1966) & Manure $^{5)}$ & 29 & 2690 & 96 & 6.5 & & & & \\
\hline Laukaa & Silt loam & $1964-73$ & Unlimed & 72 & 2280 & 83 & 4.4 & 6.0 & & & 3 \\
\hline 62.50 & & (1973) & Limed ${ }^{6)}$ & 72 & 2250 & 92 & 7.0 & 6.6 & & & \\
\hline $\begin{array}{l}\text { Mikkeli } \\
61.40\end{array}$ & $\begin{array}{l}\text { Fine sand } \\
\text { (potato) }\end{array}$ & $1965-67$ & No & 174 & 23.9 & 90 & 15.7 & 5.9 & & & 4 \\
\hline $\begin{array}{l}\text { Laukaa } \\
62.20\end{array}$ & $\begin{array}{l}\text { Silt loam } \\
\text { (potato) }\end{array}$ & $1965-67$ & No & 174 & 24.1 & 90 & 7.7 & 5.5 & & & 4 \\
\hline $\begin{array}{l}\text { Maaninka } \\
63.10\end{array}$ & $\begin{array}{l}\text { Fine sand } \\
\text { (potato) }\end{array}$ & $1965-67$ & No & 174 & 23.3 & 96 & 21.3 & 6.0 & & & 4 \\
\hline $\begin{array}{l}\text { Ruukki } \\
64.40\end{array}$ & $\begin{array}{l}\text { Fine sand } \\
\text { (potato) }\end{array}$ & $1965-67$ & No & 174 & 21.0 & 95 & 15.2 & 5.9 & & & 4 \\
\hline $\begin{array}{l}\text { Hartola } \\
61.30\end{array}$ & $\begin{array}{l}\text { Sandy till } \\
\text { (Grass) }\end{array}$ & $1977-79$ & No & 60 & 6340 & 92 & 8.6 & 5.5 & & & 5 \\
\hline $\begin{array}{l}\text { Pihtipudas } \\
63.25\end{array}$ & $\begin{array}{l}\text { Silt loam } \\
\text { (Grass) }\end{array}$ & 1978-79 & No & 60 & 5070 & 85 & 3.0 & 5.4 & & & 5 \\
\hline $\begin{array}{l}\text { Muhos } \\
64.45\end{array}$ & $\begin{array}{l}\text { Fine sand } \\
\text { (Grass) }\end{array}$ & $1978-79$ & No & 60 & 5530 & 96 & 17.5 & 5.9 & & & 5 \\
\hline $\begin{array}{l}\text { Muhos } \\
64.45\end{array}$ & $\begin{array}{l}\text { Fine sand } \\
\text { (Grass) }\end{array}$ & 1978-79 & No & 60 & 4940 & 90 & 4.8 & 5.3 & & & 5 \\
\hline $\begin{array}{l}\text { Toholampi } \\
50.50\end{array}$ & $\begin{array}{l}\text { Fine sand } \\
\text { (Grass) }\end{array}$ & 1983-86 & No & 50 & 4320 & 85 & 7.6 & 5.3 & & & 5 \\
\hline $\begin{array}{l}\text { Jokioinen } \\
60.50\end{array}$ & $\begin{array}{l}\text { Sa loam } \\
\text { (potato) }\end{array}$ & 1987-89 & No & 100 & 35.6 & 97 & 36.5 & 6.5 & & & 6 \\
\hline $\begin{array}{l}\text { Mouhijärvi } \\
61.30\end{array}$ & $\begin{array}{l}\text { Silt loam } \\
\text { (Grass) }\end{array}$ & 1990-93 & No & 36 & 6280 & 95 & 9.8 & 5.8 & & & 7 \\
\hline $\begin{array}{l}\text { Maaninka } \\
63.10\end{array}$ & $\begin{array}{l}\text { Fine sand } \\
\text { (Grass) }\end{array}$ & 1991-94 & No & 36 & 6080 & 95 & 9.7 & 5.4 & & & 7 \\
\hline
\end{tabular}

1) Yield units $1.0 \mathrm{~kg}$ grain, $0.5 \mathrm{~kg}$ rapeseed or feed units grass equivalent to $1 \mathrm{~kg}$ barley or tonnes of potatoes

2) Relative control yields in per cent of the yield obtained with sufficient fertilisation

${ }^{3)}$ Acid ammonium acetate extractable $\mathrm{P}$ in $\mathrm{mg} \mathrm{dm}^{-3}$ soil

${ }^{4)}$ References: 1 = Salonen and Tainio 1956, 2 = Luostarinen 1967, 3 = Jaakkola et al. 1977, 4 = Varis 1972, 5 = Saarela and Elonen 1982, 6 = Saarela 1992b and unpublished data (UPD), Saarela et al. 1995, 7 = Hakkola 1998 and UPD.

5) $\mathrm{P}$ application in manure $7 \mathrm{~kg} \mathrm{ha}^{-1} \mathrm{a}^{-1}$

${ }^{6)}$ Ground limestone 8 tonnes per hectare 
Saarela, I. et al. Effects of repeated phosphorus fertilisation on field crops: silty and sandy soils

Table 2. Soil characteristics and $\mathrm{P}$ status of the plough layer at each experimental sites.

\begin{tabular}{|c|c|c|c|c|c|c|c|c|c|c|c|c|c|c|}
\hline \multirow{2}{*}{$\begin{array}{l}\text { No/ Location } \\
\text { group }\end{array}$} & \multirow{2}{*}{$\begin{array}{l}\text { Orga- } \\
\text { nic } \\
\text { C, } \%\end{array}$} & \multirow{2}{*}{$\begin{array}{c}\text { Clay } \\
\%\end{array}$} & \multirow{2}{*}{$\underset{\text { 1) }}{\mathrm{pH}_{\mathrm{w}}}$} & \multirow{2}{*}{$\begin{array}{c}\mathrm{S}^{2)} \\
\mathrm{cmol}^{(+)} \\
\mathrm{dm}^{-3}\end{array}$} & \multirow{2}{*}{$\begin{array}{l}\text { Total } \\
\mathrm{P} \\
\mathrm{g} \mathrm{kg}^{-1}\end{array}$} & \multirow{2}{*}{$\begin{array}{c}\text { P satu- }{ }^{3)} \\
\text { ration } \\
\%\end{array}$} & \multirow{2}{*}{$\begin{array}{c}\text { Sorp-4) } \\
\text { tion } \\
\text { index }\end{array}$} & \multicolumn{7}{|c|}{ Soil test $\mathrm{P}$ values, $\mathrm{P}_{\mathrm{x}},{ }^{5)}$ where $\mathrm{x}=$} \\
\hline & & & & & & & & Ac & w60 & Olsenm & $\mathrm{AL}$ & $\mathrm{CaL}$ & $\mathrm{CaCl}_{2}$ & res \\
\hline 9 Mouh & 2.4 & 35 & 5.7 & 8.5 & 0.86 & 6.8 & 0.50 & 3.7 & 6.7 & 26 & 54 & 50 & 0.6 & 65 \\
\hline 10 Tohmajärvi & 3.5 & 5 & 5.6 & 4.9 & 1.00 & 6.6 & 2.10 & 4.6 & $(4.6)$ & 36 & 50 & 30 & 0.2 & 50 \\
\hline 1 Toholampi & 2.9 & 6 & $5.4^{1)}$ & 2.3 & 0.85 & 4.5 & 1.66 & 4.7 & 1.6 & 40 & 41 & 40 & 0.1 & 40 \\
\hline 2 Anjalankoski & 9.8 & 25 & 6.0 & 12.3 & n.d. & 6.8 & 0.49 & 6.9 & 5.4 & n.d. & n.d. & n.d & n.d. & n.d. \\
\hline 3 Toholampi & 9.7 & 18 & 4 & 3. & n.d. & 7.5 & 1.74 & 7.0 & 3.5 & 11. & n.d & n.d. & n.d. & n.d. \\
\hline 4 Mikkeli & 4.6 & 3 & 5.8 & 4.8 & 0.78 & 7.5 & 1.57 & 8.2 & 5.3 & 94 & 88 & 75 & 0.4 & 70 \\
\hline $9-14$ & 5.5 & 15 & 5.6 & 6.0 & 0.87 & 6.5 & 1.34 & 5.8 & 4.5 & 49 & 58 & 49 & 0.3 & 56 \\
\hline 15 Maaninka & 1.6 & 8 & 6.1 & 8.2 & 1.87 & 11.7 & 0.28 & 14.2 & 11.4 & 44 & 83 & 120 & 1.8 & 126 \\
\hline 16 Mouhijärvi & 2.9 & 33 & 6.5 & 11.5 & 1.41 & 11.5 & 0.43 & 15.2 & 15.0 & 51 & 121 & 150 & 1.3 & 156 \\
\hline 17 Laukaa & 2.7 & 26 & 6.2 & 10.6 & 1.22 & 12.4 & 0.11 & 27.8 & 18.6 & 66 & 166 & 220 & 4.3 & 166 \\
\hline 18 Jokioinen & 2.9 & 10 & 6.4 & 11.2 & 1.62 & n.d. & 0.13 & 60.0 & 42.0 & 117 & 262 & 310 & 5.2 & 448 \\
\hline $15-18$ & 2.5 & 19 & 6.3 & 10.4 & 1.53 & 11.9 & 0.24 & 29.3 & 21.8 & 69 & 158 & 200 & 3.0 & 224 \\
\hline $9-18$ & 4.3 & 17 & 5.9 & 7.8 & 1.20 & 8.3 & 0.90 & 15.2 & 11.4 & 59 & 108 & 124 & 1.7 & 140 \\
\hline
\end{tabular}

1) At site 11 soil $\mathrm{pH}$ increased to 5.8 after applying $5 \mathrm{t} \mathrm{ha}^{-1}$ of ground limestone in 1982

2) $\mathrm{S}=$ sum of extractable $\mathrm{Ca}, \mathrm{K}$ and $\mathrm{Mg}$ measured by the acid ammonium acetate method

3) Fluoride and hydroxide extractable $\mathrm{P}$ divided by acid oxalate extractable $\mathrm{Al}$ and Fe (Hartikainen 1989)

4) Sorption of $0.2 \mathrm{~g} \mathrm{P} \mathrm{kg}^{-1}$ soil in $0.005 \mathrm{M} \mathrm{CaCl}_{2}$ in one week divided by the final solution $\mathrm{P}$ concentration,

$\left(\mathrm{g} \mathrm{kg}^{-1}\right)\left(\mathrm{mg} \mathrm{dm}^{-3}\right)^{-1}$ (Saarela 1992a)

5) $\mathrm{P}_{\mathrm{w} 60}=$ water extraction, ratio1:60 by volume, $\mathrm{P}_{\mathrm{Olsenm}}=$ modified Olsen $\mathrm{P}$ (20\% higher than standard because of longer extraction), $\mathrm{P}_{\mathrm{AL}}=$ ammonium lactate extraction $\left(\mathrm{mg} \mathrm{P} \mathrm{kg}^{-1}\right)$ by Swedish Agricultural University, Sweden (S. Engblom), $\mathrm{P}_{\mathrm{CaL}}=$ calcium lactate extraction $\left(\mathrm{mg} \mathrm{P} \mathrm{kg}^{-1}\right)$ by Estonian Research Institute of Agriculture, Estonia $(\mathrm{L} . \mathrm{Kevvai}), \mathrm{P}_{\mathrm{CaCl} 2}=$ $0.01 \mathrm{M} \mathrm{CaCl}_{2}$ extraction ( $\mathrm{mg} \mathrm{P} \mathrm{kg}^{-1}$ ) by Wageningen Agricultural University, the Netherlands $\left(\mathrm{S}\right.$. van der Zee), $\mathrm{P}_{\text {res }}=$ resin extraction ( $\mathrm{mg} \mathrm{P} \mathrm{dm}^{-3}$ ) by Institute of Agriculture, Brazil (B. van Raij)

dure of this test (20\% higher) are very high compared to the $\mathrm{P}_{\mathrm{w}}$ values. In some European soils $\mathrm{P}_{\mathrm{w}}$ have represented almost fifty percent of $\mathrm{P}_{\text {Olsen }}(\mathrm{Sib}-$ besen and Sharpley 1997). In the present material (Table 2), the corresponding ratio is similar in the soils which had high $\mathrm{P}_{\mathrm{w}}$ values (soils 15-18), but even tenfold in the soils which had low $\mathrm{P}_{\mathrm{w}}$ values (soils 9-14). In 224 moderately acid mineral soils of Ireland (Herlihy et al. 2006), Olsen P values (mean $\left.16.3 \mathrm{mg} \mathrm{kg}^{-1}\right)$ correlated rather loosely $(\mathrm{r}=$ 0.47 ) with $\mathrm{CaCl}_{2} \mathrm{P}$ values (mean $1.5 \mathrm{mg} \mathrm{kg}^{-1}$ ), but more closely $(r=0.69)$ with the Morgan $P$ values (mean $7.4 \mathrm{mg} \mathrm{kg}^{-1}$ ) which are 0.7 times $\mathrm{P}_{\mathrm{Ac}}$ (Saarela et al. 2004). The simple regression equations between $\mathrm{P}_{\mathrm{Ac}}$ or Morgan $\mathrm{P}$ and other soil tests are not reliable, but the acetate $\mathrm{P}$ values can be derived form other soil test $\mathrm{P}$ values by using conversion equations based on $\mathrm{pH}$ and some other soil properties (Ketterings et al. 2002).

\section{Treatments and cropping}

The treatments consisted of a control and four rates of annual P application: 0, 15, 30, 45 and $60 \mathrm{~kg} \mathrm{P}$ $\mathrm{ha}^{-1}$ as single (1977-1987) or triple superphosphate $(8.7$ or $20 \%$ P). The plot size varied between $4-5 \mathrm{~m}$ by $12-20 \mathrm{~m}$. The main experimental plants were spring barley (Hordeum vulgare L.), oats (Avena sativa L.) and perennial grass (mainly Phleum pratense L.), while spring wheat (Triticum aestivum L.), oilseed rape (Brassica rapa L. subsp. oleifera DC.) and winter rye (Secale cereale L.) were also grown in irregular rotations. Potato 
Vol. 15 (2006): 423-443.

(Solanum tuberosum L.) was the main crop at one site (Table 3). For potatoes, the P rates were 1.67fold, (0-100 $\left.\mathrm{kg} \mathrm{P} \mathrm{ha}^{-1}\right)$ and only applied to potato grown in eight of the twelve years.

Before sowing cereals, oilseed rape, and potatoes, the $\mathrm{P}$ fertiliser was applied with hoe coulters in narrow bands or rows at a distance of 12.5 or 15 $\mathrm{cm}$ at a depth of $8 \mathrm{~cm}$. For ley, the $\mathrm{P}$ fertiliser was broadcast at the beginning of the growing season. Potassium was applied as $\mathrm{K}_{2} \mathrm{SO}_{4}$ for potatoes (150 $\mathrm{kg} \mathrm{K} \mathrm{ha}{ }^{-1}$ ) and as a high-grade $\mathrm{KCl}$ fertiliser for other crops $\left(60 \mathrm{~kg} \mathrm{~K} \mathrm{ha}^{-1}\right)$. The $\mathrm{K}$ fertiliser was broadcast for ley once for each cut and applied across the $P$ fertiliser rows at a depth of 5 to $8 \mathrm{~cm}$ for other crops. Soil 11 was treated with $5 \mathrm{t} \mathrm{ha}^{-1}$ of ground limestone in the early 1980s. Oilseed rape was fertilised with boron. All insufficient nutrients were to be applied by the local experts, but other fertilisers than those mentioned above were not used. A marginal deficiency of sulphur was possible in the control treatment, which received no superphosphate.

In order to measure the residual effects of previously applied $\mathrm{P}$, the $\mathrm{P}$ rates 30 and $60 \mathrm{~kg} \mathrm{ha}^{-1}$ were withdrawn beginning in the thirteenth year at sites 9,11 and 15 . The corresponding $P$ rates for potatoes, 50 and $100 \mathrm{~kg} \mathrm{ha}^{-1}$, were withdrawn beginning in the tenth year at site 18 . For the last one to three years, the plots were split in terms of NK and NPK fertilisations by applying suitable com-

Table 3. Crop succession and the rates of nitrogen fertilisation $\left(\mathrm{N} \mathrm{kg} \mathrm{ha}^{-1}\right)$ applied at the experimental sites $9-18$ in the crop years 1977-1994.

\begin{tabular}{|c|c|c|c|c|c|c|c|c|c|c|c|c|c|c|c|c|c|c|}
\hline Exp. & 77 & 78 & 79 & 80 & 81 & 82 & 83 & 84 & 85 & 86 & 87 & 88 & 89 & 90 & 91 & 92 & 93 & 94 \\
\hline \multirow[t]{2}{*}{9} & & & bar & bar & oat & oat & bar & bar & bar & oat & oilr & sw & bar & oat & rye* & bar & oat & \\
\hline & & & 80 & 80 & 80 & 80 & 82 & 82 & 82 & 82 & 100 & 100 & 83 & 83 & 90 & 90 & 90 & \\
\hline \multirow[t]{2}{*}{10} & oat & oat & oat & oat & oat & oat & bar & oat & bar & bar & bar & oat & & & & & & \\
\hline & 75 & 75 & 75 & 75 & 75 & 75 & 75 & 75 & 75 & 75 & 75 & 75 & & & & & & \\
\hline \multirow[t]{2}{*}{11} & bar & bar & bar & bar & bar & bar & bar & bar & bar & bar & bar & bar & $b a r^{*}$ & bar & bar & bar\# & & \\
\hline & 61 & 61 & 61 & 61 & 61 & 61 & 61 & 61 & 61 & 61 & 61 & 61 & 61 & 61 & 61 & 61 & & \\
\hline \multirow[t]{2}{*}{12} & bar & bar & bar & bar & bar & bar & (fal) & bar & bar & bar & bar & bar & sw & & & & & \\
\hline & 80 & 55 & 55 & 55 & 55 & 55 & - & 55 & 55 & 55 & 55 & 55 & 138 & & & & & \\
\hline \multirow[t]{2}{*}{13} & & oat & grl & grl & grl & grl & ofgrl & grl & grl & grl & & & & & & & & \\
\hline & & 61 & 200 & 120 & 250 & 200 & 200 & 200 & 200 & 200 & & & & & & & & \\
\hline \multirow[t]{2}{*}{14} & & bar & grl & grl & grl & grl & bar & bar & bar & bar & & & & & & & & \\
\hline & & 55 & 200 & 300 & 300 & 300 & 60 & 60 & 60 & 60 & & & & & & & & \\
\hline \multirow[t]{2}{*}{15} & bar & bar & bar & bar & bar & bar & bar & bar & bar & bar & bar & bar & $b a r^{*}$ & bar & bar & bar\# & bar & oat \\
\hline & 80 & 80 & 60 & 50 & 50 & 80 & 80 & 80 & 80 & 80 & 80 & 80 & 80 & 80 & 80 & 57 & 57 & 57 \\
\hline \multirow[t]{2}{*}{16} & bar & $\mathrm{gcl}$ & $\mathrm{gcl}$ & grl & oat & bar & bar & grl & grl & grl & grl & oat & bar* & $s w$ & bar & gcl\# & & \\
\hline & 80 & 240 & 240 & 240 & 82 & 82 & 82 & 200 & 200 & 200 & 200 & 83 & 83 & 83 & 83 & 110 & & \\
\hline \multirow[t]{2}{*}{17} & oat & bar & bar & oat & bar & bar & bar & bar & oat & bar & bar & oat & & & & & & \\
\hline & 82 & 82 & 82 & 68 & 68 & 68 & 68 & 68 & 68 & 68 & 68 & 69 & & & & & & \\
\hline \multirow[t]{2}{*}{18} & & & & pot & pot & pot & pot & (sw) & pot & (bar) & $(\mathrm{gcl})$ & $(\mathrm{gcl})$ & pot*\# & $\underline{p o t}$ & $\underline{p o t}$ & & & \\
\hline & & & & 90 & 90 & 90 & 90 & 100 & 90 & 60 & 45 & 45 & 90 & 90 & 60 & & & \\
\hline
\end{tabular}

Crop abbreviations: $\mathrm{sw}=$ spring wheat, bar $=$ spring barley, oilr $=$ oilseed rape (spring turnip rape), grl = grass ley, rye $=$ winter rye, $\mathrm{ww}=$ winter wheat, $\mathrm{gcl}=$ grass clover ley, $(\mathrm{fal})=$ fallow (uncropped, no P applied), pot = potato Italicising indicates withdrawal of the $\mathrm{P}$ application rates 30 and $60 \mathrm{~kg} \mathrm{ha}^{-1}$ (rates 50 and $100 \mathrm{~kg} \mathrm{ha}^{-1}$ in potato) beginning in the year marked with * (15 and $45 \mathrm{~kg} \mathrm{ha}^{-1}$ continued). No P was applied to the crops in experiment 18 marked with parentheses.

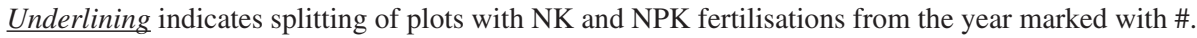


Saarela, I. et al. Effects of repeated phosphorus fertilisation on field crops: silty and sandy soils

pound fertilisers instead of the $\mathrm{N}$ and $\mathrm{K}$ fertilisers (Table 3). The two P treatments supplied exactly the same amount of $\mathrm{N}$, and the minor differences in $\mathrm{K}$ and other nutrients were considered negligible.

When superphosphate was applied to the four treatments, the control was usually drilled in the same way without any fertiliser distribution. The $\mathrm{N}$ fertiliser "Oulunsalpietari", a Finnish ammonium nitrate granulated with a mixture of ground dolomite, was applied with a combi drill at the same time that the seeds were planted and drilled across the $\mathrm{P}$ fertiliser rows to a depth of $8 \mathrm{~cm}$. The amounts of $\mathrm{N}$ applied each year are given in Table 3. A more detailed description of the treatments and cultivation were presented earlier (Saarela et al. 2006). At the more northern sites on the more capillary silty and sandy soils, spring sowing was done later than on the southern clays, normally between 15 May and 5 June.

A summary of the weather conditions at Mikkeli during the experimental period is presented in Table 4, and the weather data for Jokioinen were reported earlier (Saarela et al. 2006). The 1981 and 1987 seasons and the early 1982 season were cool and the 1986, 1988 and 1989 seasons were warm. Most of the seasons in the early and middle years of the study had average or higher
(1981, 1987 and 1993) precipitation, but the 1986 and 1992 seasons were rather dry.

\section{Testing and presentation of results}

The five $\mathrm{P}$ fertilisation treatments were arranged in randomised blocks and four replicates were made. Differences between the treatments were tested by analysis of variance for each year and for the whole study period and its parts. Results from the former and present studies were examined on the basis of the yield responses to increasing amounts of $\mathrm{P}$ fertilisation in relation to the soil-test $\mathrm{P}$ values $\left(\mathrm{P}_{\mathrm{Ac}}\right)$ determined by the Finnish acid ammonium acetate method ( $0.5 \mathrm{M}$ acetic acid, $0.5 \mathrm{M}$ ammonium acetate, $\mathrm{pH} 4.65,1 / 10(\mathrm{v} / \mathrm{v})$ for $1 \mathrm{~h}$, Vuorinen and Mäkitie 1955). The relationship between the yield effects of applied P and the chemically estimated supply of $\mathrm{P}$ from the soils was examined graphically by means of $\mathrm{RCY} / \mathrm{P}_{\mathrm{Ac}}$ plots. Sufficient and optimum rates of $\mathrm{P}$ fertilisation were interpolated from the relative yields (RY) obtained with the five treatments.

The amounts of repeated $\mathrm{P}$ fertilisation that were required to produce optimum yields were used as the main criterion for determining sufficient $\mathrm{P}$ fertilisation, as is frequently done in inter-

Table 4. Monthly mean temperature $\left({ }^{\circ} \mathrm{C}\right)$ and precipitation $(\mathrm{mm})$ at Mikkeli, eastern Finland $\left(61^{\circ} .40^{\prime}\right.$ N, $2^{\circ} .13^{\prime}$ E) during the growing seasons 1977-1994 and the means of the period 1961-1990.

\begin{tabular}{|c|c|c|c|c|c|c|c|c|c|c|c|c|c|c|c|c|c|c|c|}
\hline & 77 & 78 & 79 & 80 & 81 & 82 & 83 & 84 & 85 & 86 & 87 & 88 & 89 & 90 & 91 & 92 & 93 & 94 & 61-90 \\
\hline \multicolumn{20}{|l|}{${ }^{\circ} \mathrm{C}$} \\
\hline May & 8.9 & 10.0 & 10.9 & 7.0 & 10.8 & 8.5 & 11.4 & 13.0 & 8.3 & 10.6 & 7.7 & 11.0 & 10.7 & 8.7 & 7.1 & 11.0 & 12.5 & 7.6 & $\begin{array}{ll}6 \quad 9.4\end{array}$ \\
\hline Ine & .9 & 14.1 & 15.0 & 17.2 & 13.2 & 10.3 & 13.6 & 13.6 & 13.2 & 17.1 & 13.0 & 16.4 & 16.3 & 13.3 & 13.0 & 15.9 & 11.0 & 13.1 & 114.4 \\
\hline July & 4.8 & 15.3 & 15.0 & 16.2 & 16.9 & 16.7 & 17.3 & 15.4 & 15.4 & 16.8 & 14.8 & 19.7 & 16.8 & 15.1 & 16.7 & 15.3 & 15.4 & 18.7 & $\begin{array}{ll}7 & 16.1\end{array}$ \\
\hline ugus & 13.4 & 12.6 & 15.4 & 14.0 & 13.2 & 14.7 & 14.2 & 13.7 & 15.7 & 12.7 & 11.0 & 13.6 & 13.8 & 15.1 & 15.5 & 13.6 & 12.7 & 14.6 & $\begin{array}{lll}6 & 14.1\end{array}$ \\
\hline \multicolumn{20}{|l|}{$\mathrm{mm}$} \\
\hline 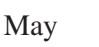 & 5 & 5 & 47 & 42 & 22 & 45 & 82 & 44 & 63 & 37 & 42 & 40 & 32 & 33 & 31 & 13 & 18 & 29 & 39 \\
\hline June & 37 & 66 & 43 & 79 & 97 & 62 & 76 & 65 & 32 & 12 & 132 & 85 & 55 & 48 & 86 & 15 & 98 & 35 & 53 \\
\hline July & 93 & 45 & 116 & 36 & 121 & 46 & 36 & 107 & 102 & 78 & 57 & 28 & 59 & 102 & 71 & 62 & 69 & 59 & 69 \\
\hline ugust & 53 & 73 & 53 & 105 & 89 & 90 & 75 & 41 & 65 & 95 & 114 & 120 & 121 & 77 & 115 & 951 & 104 & 101 & 85 \\
\hline
\end{tabular}


Vol. 15 (2006): 423-443.

preting fertilisation experiments (Sippola 1980, Munk et al. 2005). The relative yields can also be related to the corresponding soil test $\mathrm{P}$ values (Dodd and Mallarino 2005), and both those factors can be examined together (Saarela et al. 1995).

The relative control yield was a useful parameter in defining the optimum value of soil $\mathrm{P}_{\mathrm{Ac}}$ for the less responsive clay and loam soils (Saarela et al. 2006), in which the rates of $P$ required to produce optimum yields and to maintain the $\mathrm{P}_{\mathrm{Ac}}$ values were similar. The common optimum point of fertilisation and soil $\mathrm{P}$ represented, at least apparently according to the soil test, a steady status of soil P. In most of the silty and sandy soils of this study the sufficient rate of $\mathrm{P}$ was much higher than required to maintain the soil $\mathrm{P}_{\mathrm{Ac}}$ value. The optimum rate of $\mathrm{P}$ fertilisation corresponded therefore to a transient status of soil $\mathrm{P}$.

\section{Results and discussion}

\section{Cumulative yield responses and soil characteristics}

\begin{abstract}
A graphical summary of the cumulative yields obtained at the ten sites is presented in Fig. 2. The effect of $\mathrm{P}$ fertilisation was usually significant and moderately large, but it was not found on the soils that had high soil test $\mathrm{P}$ values, as measured by the acid ammonium acetate method $\left(\mathrm{P}_{\mathrm{Ac}}\right)$. In addition to the chemically estimated availability of $\mathrm{P}$, other properties of the individual soils, crops, and weather conditions also affected the efficacy of applied
\end{abstract} P.

The relatively small yield responses to P fertilisation on the chemically highly P-deficient but
Fig. 2. Effects of different amounts of repeated annual $\mathrm{P}$ fertilisation on cumulative yield on ten silty and sandy soils in Finland for 9 to 18 successive seasons. The values 30' (33') and 60' (66') indicate residual effects of previous fertilisation in the last years as specified in Table 3. One yield unit $\left(\mathrm{kg}^{*}\right)$ corresponds to $1.0 \mathrm{~kg}$ of cereal grain or one grass feed unit which is equivalent to $1.0 \mathrm{~kg}$ of barley grain or $7.0 \mathrm{~kg}$ of potatoes. Abbreviations of texture: sicl = silty clay loam, $\mathrm{sl}=$ sandy loam, sil = silt loam, ls = loamy sand. Asteriks indicate significant effect of $\mathrm{P}$ fertilisation $(\mathrm{P}): *=<0.05, * *=<0.01$ and $* * *=<0.001,-=$ not significant.

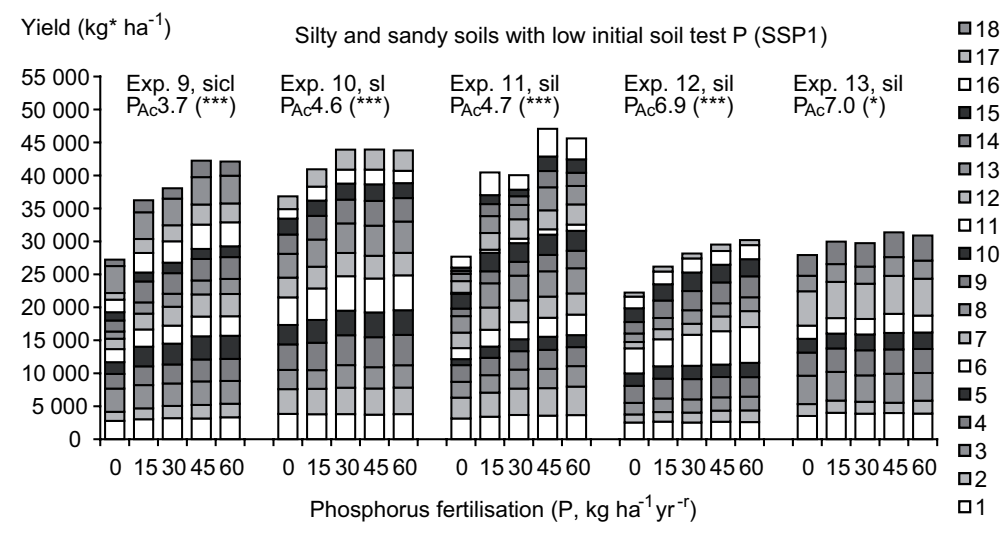

Yield $\left(\mathrm{kg}^{*} \mathrm{ha}^{-1}\right)$ Silty and sandy soils with medium to high initial soil test P (SSP2, Exo. 14 SSP1)

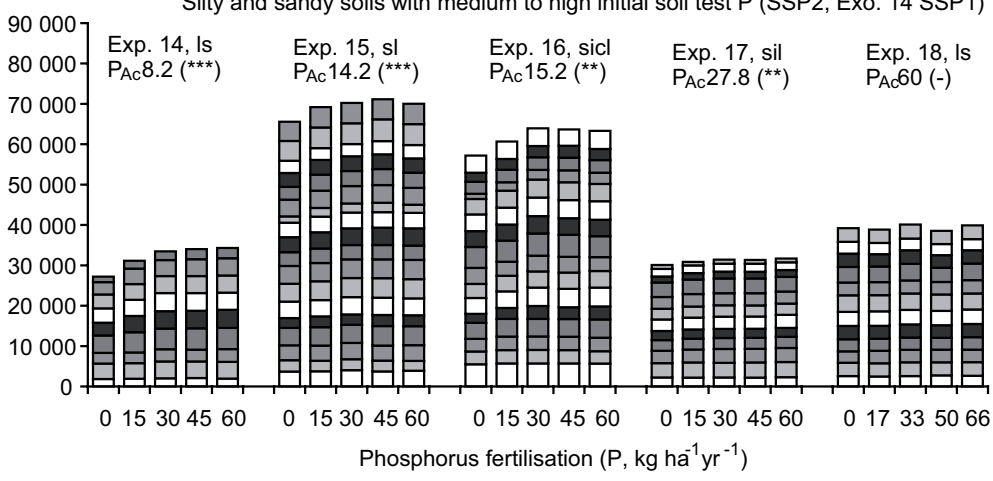


Saarela, I. et al. Effects of repeated phosphorus fertilisation on field crops: silty and sandy soils

physically favourable silt loam soil 10 in Tohmajärvi resulted from bad early lodging of barley in 1985 and 1986 (cultivar Arra) and a small yield in the rainy season of 1987 . The mean control yield of barley grown for four years was $2450 \mathrm{~kg} \mathrm{ha}^{-1}$. At this site, the yield effect of $\mathrm{P}$ fertilisation was exceptionally greater in oats than in barley, but higher rates than $30 \mathrm{~kg} \mathrm{P} \mathrm{ha}^{-1}$ were not beneficial. At the $P$ fertilisation rates of $0-45 \mathrm{~kg} \mathrm{ha}^{-1}$, the final $\mathrm{P}_{\mathrm{Ac}}$ values for soil 10 were $3.3-6.0 \mathrm{mg} \mathrm{dm}^{-3}$ and the final $\mathrm{P}_{\mathrm{w}}$ values $1.5-3.1 \mathrm{mg} \mathrm{dm}^{-3}$. The $\mathrm{P}_{\mathrm{Ac}}$ values were thus lower than the corresponding values for soil 11, the most responsive soil (see Fig. 3), and the $\mathrm{P}_{\mathrm{w}}$ values were similar.

The most enriched soil at site 18, Jokioinen, supplied sufficient $\mathrm{P}$ even for the very demanding crop of potato. However, marginal effects of $\mathrm{P}$ were obtained in the moderately dry season of 1983, when the response was significant with a probability of $93 \%$ and tuber $\mathrm{P}$ concentration was rather low (data not shown). In the dry season of 1992, the effect of $80 \mathrm{~kg} \mathrm{P}^{-1}$ applied as diammonium phosphate in the subplots was highly significant and fairly large, almost ten per cent (Saarela et al. 1995). In the multi-factorial experiment carried out on a more clayey loam soil (approximately 20\% clay) in Jokioinen from 1987 to 1989, the effect of $\mathrm{P}$ fertilisation was small but significant at a mean $\mathrm{P}_{\mathrm{Ac}}$ value of $36.5 \mathrm{mg} \mathrm{dm}^{-3}$.

The responsive silt loam soil 12 in Anjalankoski was located in a similar flat landscape, and its plough layer was physically and chemically comparable to the non-responsive soil 6 in Kokemäki (Saarela et al. 2003, 2006). The main causal difference between these soils was probably the compacted structure and poor $\mathrm{P}$ status in the subsoil layer of the responsive soil 12. At this site, the enriched plough layer was also rather shallow. The surface soil had a low concentration of water-extractable $\mathrm{P}$, but it supplied $\mathrm{P}$ to pot-grown crops as well as the unresponsive soil 6. Soil 12 was not very acid $\left(\mathrm{pH}_{\mathrm{w}} 6.0\right)$, but the other silty loam soil rich in organic matter (soil 13) was; its $\mathrm{pH}_{\mathrm{w}}$ of 4.9 was rather low even for the acid-tolerant crops oats and timothy.

The moderately acid soils 9,11 , and 14 as well as the weakly acid soils 16 and 17 responded to $P$ fertilisation fairly strongly in relation to their initial $P_{A c}$ values (Fig. 2). The acid sandy soils 11 and 14 had rather low final $\mathrm{P}_{\mathrm{w}}$ values even with the large balance surplus caused by the repeated application of $45 \mathrm{~kg} \mathrm{P} \mathrm{ha}^{-1}$ (Fig. 3). The richer sandy loam 15 and the silty clay loam soils 9 and 16 had higher $\mathrm{P}_{\mathrm{w}}$ values in relation to their $\mathrm{P}_{\mathrm{Ac}}$ values (Fig. 4). The silty loam soil 9 performed well in a pot experiment, while the infertile sandy soils $(10,11$, 14) supplied little $P$ even after heavy liming (Saarela et al. 2003).

The unstable silty soils $9,11,16$, and 17 were very easily compacted by rainfall. The massive structure of compacted silty soils causes a strong capillary rise of water to the surface during dry periods. Because of the ensuing deep drying through evaporation, silty soils are sensitive to drought, although their water-holding capacity is large. Since plants tend to root weakly in compacted soils, the supply of $\mathrm{P}$ is frequently physically restricted in such soils. The most responsive silty soils 9 and 11 and the loamy sand 14 were rather strongly acid, but heavy liming of the same soils in pot experiments showed that liming was less beneficial in sandy soils than in clay soils (Saarela et al. 2003).

\section{Yield variation at five sites}

The yields obtained with three different treatments on three P-deficient soils during successive years are presented in Fig. 3. Because soil moisture and other physical conditions depended on weather conditions, the yields of the silty soils 9 and 11 varied widely between individual seasons. The control yields were generally small and decreased with time. Essential results from these problem soils were the large yield increases obtained with $\mathrm{P}$ fertilisation and the high rates of $\mathrm{P}$ required to produce maximum yields. During the last five years, the amount of $\mathrm{P}$ fertilisation equivalent to the $\mathrm{P}$ harvested in the small grain yields of spring cereals, about $5 \mathrm{~kg} \mathrm{ha}^{-1}$, would have produced no more than $50 \%$ of the yields received with sufficient $\mathrm{P}$ fertilisation. On soil 9, large application rates of $\mathrm{P}$ fertiliser were required even for oats, which im- 
Vol. 15 (2006): 423-443.

plied that the poor availability of $\mathrm{P}$ in this soil was not entirely caused by acidity.

The cool and rainy weather of the years 1981 and 1987 was detrimental on the more northern silt loam soil 11 . On the clay loam soil 9 at the more sloping site, the rainy season of 1981 was favourable for the supply of $\mathrm{P}$ to oats, in the same way as on a loam soil studied by Jaakkola et al. (1997). Another good performance of crop with the control treatment was found in the winter rye grown on soil 9 in 1990-1991, when the weather conditions were obviously favourable for root growth and nutrient absorption. The slightly peculiar variation of the yield responses on this soil was not caused by any errors in the treatments or in harvesting and weighing the yields.

The acid and possibly Ca deficient (Saarela et al. 2003) loamy sand 14 produced slightly more stable yields than the weakly aggregated silty soils (Fig. 3). In the grass ley grown from the second to the fifth year, the yield responses increased with the ley years, which is typical for perennial grasses in Finland (Saarela and Elonen 1982, Saarela et al. 1995). In soil 14 , the poor availability of $P$ was not correctly indicated by the relatively high $\mathrm{P}_{\mathrm{Ac}}$ values, but the concentration of $\mathrm{P}$ extractable in water $\left(\mathrm{P}_{\mathrm{w}}\right)$ was in better agreement with the need for fertilisation. The small capacity to hold water and other physical properties of very coarse-textured soils are not favourable for P uptake (van Noordwijk et al. 1990), which means that higher $P_{w}$ values are required than in fine-textured soils.

The yield responses measured on the sandy loam soil 15 in Maaninka were small, as had been predicted by the relatively high soil test $\mathrm{P}$ values (Fig. 4). A statistically significant negative effect of $\mathrm{P}$ fertilisation, caused by bad early lodging, was recorded in barley in the second year, 1978. Since then, a continuous positive trend was found, but the responses were not always statistically significant. In the warm season of 1988 , the mean temperature over the period from early June to the end of July, as measured in the neighbouring city of Kuopio, was almost three degrees higher than the respective mean of the years 1931-1960. The short and early barley variety Eero sown on June 6 matured on August 8, that is in 63 days, and produced
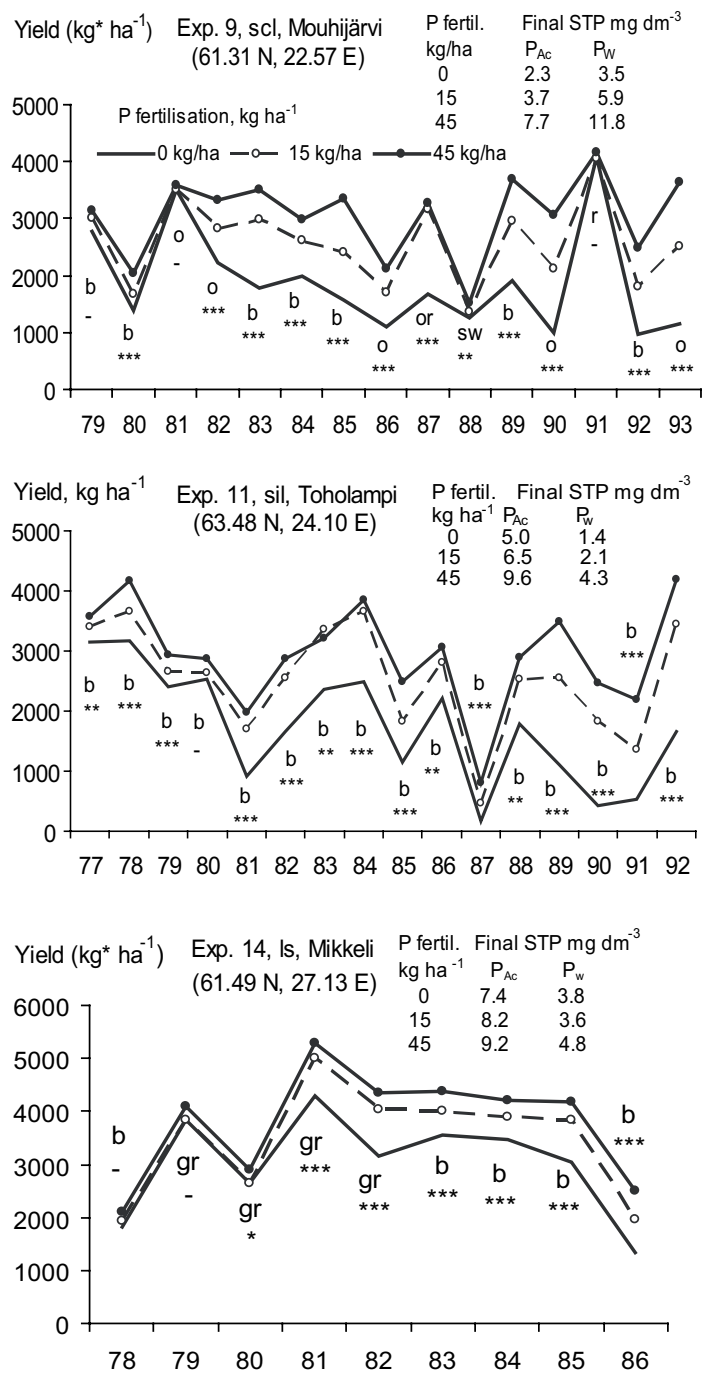

Fig. 3. Annual yield variation with three amounts of repeated $\mathrm{P}$ fertilisation on three "problem soils" requiring large amounts of $\mathrm{P}$ to produce high yields. One yield unit $\left(\mathrm{kg}^{*}\right)$ corresponds to $1.0 \mathrm{~kg}$ of cereal grain or $0.5 \mathrm{~kg}$ of rapeseed or one grass feed unit which is equivalent to 1.0 $\mathrm{kg}$ of barley grain. Abbreviations of texture: sicl = silty clay loam, sil = silt loam, ls = loamy sand. Letters denote crops: $\mathrm{b}=$ spring barley, $\mathrm{o}=$ oats, or $=$ oilseed rape, $\mathrm{sw}=$ spring wheat, $r=$ winter rye, $g r=$ grass ley. Asterisks indicate significant effect of $\mathrm{P}$ fertilisation $(\mathrm{P}): *=<0.05$, ** $=$ $<0.01$ and $* * *=<0.001,-=$ not significant.

a very small control yield, $1570 \mathrm{~kg} \mathrm{ha}^{-1}$. The effect of $\mathrm{P}$ fertilisation of $+450 \mathrm{~kg} \mathrm{ha}^{-1}$, was a crop yield increase as large as $29 \%$. 
Saarela, I. et al. Effects of repeated phosphorus fertilisation on field crops: silty and sandy soils

The silty clay loam soil 16 had fairly high initial soil test $\mathrm{P}$ and $\mathrm{pH}$ values (Table 2), but the two leys cropped for three and four years and fertilised with large amounts of $\mathrm{N}$ (Table 3) decreased the $\mathrm{pH}$ values by 0.4 units (Saarela et al. 1995). According to Lakanen and Vuorinen (1963), this pH decline was sufficient to cause the exceptionally large decrease in the $\mathrm{P}_{\mathrm{Ac}}$ values even at the zero balance (Saarela et al. 2004). The availability of $P$ in this soil appeared to be relatively good in the first years (Fig. 4.), when the concentration of $\mathrm{P}$ in grass was fairly high (data not shown). This implied that the yield effect of superphosphate measured in the rainy season of 1981 was partly caused by sulphur (Tähtinen 1977). Soil 16 had a rather unstable structure even soon after the perennial leys, which usually stabilise soil aggregates. The physical conditions were probably detrimental to rooting and caused relatively large yield responses and $\mathrm{P}$ fertilisation needs to compensate the inefficient utilisation of nutrients from the soil.

Further occasional yield responses at high $\mathrm{P}_{\mathrm{Ac}}$ values were found on the silt loam soil 17 (initial $\mathrm{P}_{\mathrm{Ac}} 27.8 \mathrm{mg} \mathrm{dm}^{-3}$ ) with barley in 1979 and 1982, when the significant (probability 99\%) effect of large amounts of $\mathrm{P}$ was more than ten per cent. Capillary silt loam soils dry slowly in the spring and are sometimes too wet and sticky during spring harrowing so that little fine loose soil is formed to prevent evaporation. Even if the seedbed preparation is successful, the mechanically formed aggregates are frequently destroyed by rainfall. Sowing too late is also detrimental, especially on silty clay loam soils.

If the soil is harrowed under suitable moisture conditions and no too intense rainfalls occur during the following weeks, the crop will successfully root and be able to utilise nutrients efficiently even
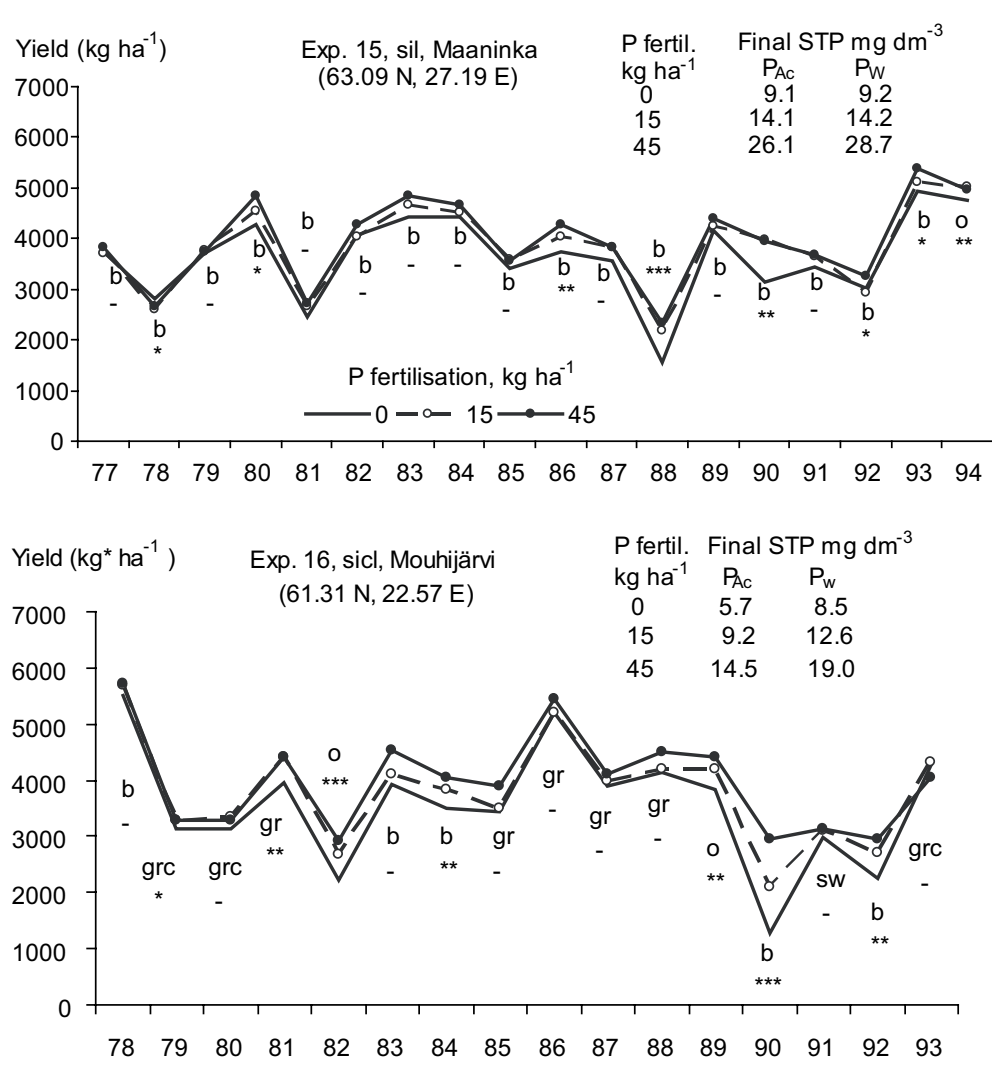

Fig. 4. Annual yield variation with three amounts of repeated $\mathrm{P}$ fertilisation on two soils that had relatively high soil test $\mathrm{P}$ values. One yield unit ( $\left.\mathrm{kg}^{*}\right)$ corresponds to 1.0 of cereal grain or one grass feed unit which is equivalent to $1.0 \mathrm{~kg}$ of barley grain. Abbreviations of texture: silt loam, sicl = silty clay loam. Letters denote crops: $b=$ spring barley, $o=$ oats, grl $=$ grass-clover ley, $\mathrm{gr}=$ grass ley, $\mathrm{sw}=$ spring wheat. Asterisks indicate significant effect of $\mathrm{P}$ fertilisation $(\mathrm{P}): *=<0.05, * *=$ $<0.01$ and $* * *=<0.001,-=$ not significant. 
Vol. 15 (2006): 423-443.

in silty soils. If the ley is successfully established, perennial grasses are much less sensitive to physical soil conditions than spring cereals are. Grasses are able to develop a dense root system even in the compacted massive soils typical of silty soils in the northern conditions of Finland. The special problems of $\mathrm{P}$ nutrition found in spring cereals on silty soils could thus be alleviated by modified production systems that are better adapted to the less favourable physical conditions.

\section{Control yield and soil $\mathrm{P}_{\mathrm{Ac}}$}

The ten silty and sandy soils of this study were tested every third year by the Finnish ammonium acetate method. The concentrations of extractable soil $\mathrm{P}$ obtained by this method $\left(\mathrm{P}_{\mathrm{Ac}}\right)$ are presented in Table 5 as the means for the entire study periods and their two or three subdivisions. During the last years, the residual effects of the previous $\mathrm{P}$ fertilisation rates of 30 and $60 \mathrm{~kg} \mathrm{ha}^{-1}$ were also compared to the continuous use of $45 \mathrm{~kg} \mathrm{P} \mathrm{ha-1}$. The relative control yields are plotted against the respective soil $\mathrm{P}_{\mathrm{Ac}}$ values in Fig. 5. Large grey circles and black triangles denote the means for the entire study periods (Table 5). Other markers denote the controls and the residual effects of the $\mathrm{P}$ amounts 30 and $60 \mathrm{~kg} \mathrm{ha}^{-1}$ and the eighteen experiments compiled in Table 1.

The recent experiments run for at least nine years at the sites that had a sufficient $\mathrm{pH}(>6.0)$ can be considered as the most useful for interpreting the $\mathrm{P}_{\mathrm{Ac}}$ values, but unfortunately there were only four such soils (Fig. 5). They do not suffice for an exact and reliable determination of the typical relationship between the effect of $\mathrm{P}$ fertilisation and the soil $\mathrm{P}_{\mathrm{Ac}}$ values. However, if the smaller responses typical of the first experimental years and of the less intensive old agriculture are taken into account, all the results from non-acid soils $\left(\mathrm{pH}_{\mathrm{w}}\right.$ $>6.0$ ) fit relatively well. With potato, the effect of $\mathrm{P}$ fertilisation was substantial also in the short-term experiments.

All the soils that produced smaller control yields than $75 \%$ were acid, but some other acid soils performed much better at the same level of
$\mathrm{P}_{\mathrm{Ac}}$ (Fig. 5). Some soils were cropped every year with timothy or oats, and even the barley varieties of this study were adapted to acid soils. The lowest RCY values occurred on the silty and acid soils 9 and 11 examined in Fig. 3. The RCY values that were obtained with the residual effects of the $\mathrm{P}$ rates of 30 and $60 \mathrm{~kg} \mathrm{P} \mathrm{ha}^{-1}$ applied twelve times were remarkably low in relation to the respective $\mathrm{P}_{\mathrm{Ac}}$ values. At site 11 , the $\mathrm{P}$ rate of $25 \mathrm{~kg}$ $\mathrm{ha}^{-1}$ applied as NPK fertiliser to the subplots in 1992 was effective in barley (Saarela et al. 1995).

In the original control plots at site 11 that were cultivated without any $\mathrm{P}$ fertilisation for 15 years, the $25 \mathrm{~kg} \mathrm{ha}^{-1}$ applied as NPK fertiliser produced a grain yield of $3610 \mathrm{~kg} \mathrm{ha}^{-1}$, which was $1960 \mathrm{~kg} \mathrm{ha}^{-1}$ more than in the control (NK). Together with the continued fertilisation with $45 \mathrm{~kg} \mathrm{P}^{-1}$, the supplemental NPK yielded $4440 \mathrm{~kg} \mathrm{ha}^{-1}$, which is 830 $\mathrm{kg} \mathrm{ha}^{-1}$ more than was measured for NPK in the previous control plots. With the residuals of the $\mathrm{P}$ rates of 30 and $60 \mathrm{~kg} \mathrm{ha}^{-1}$, NPK produced 2020 and $1150 \mathrm{~kg} \mathrm{ha}^{-1}$ more grain than NK, but the yields tended to remain smaller than was obtained with the continued use of $45 \mathrm{~kg} \mathrm{P} \mathrm{ha}^{-1}$. In this soil the availability of applied $\mathrm{P}$ declined rapidly and was poor in relation to the current $\mathrm{P}_{\mathrm{Ac}}$ values, 6.8 and $9.4 \mathrm{mg} \mathrm{dm}^{-3}$ (Table 5). On the less responsive soil 15 the effect of the supplemental P $\left(20 \mathrm{~kg} \mathrm{ha}^{-1}\right)$ applied as NPK in 1992 and 1993 was small, but it did not entirely compensate for the earlier P applications (Saarela et al. 1995).

In Finland each crop is typically fertilised with $\mathrm{P}$ every year. At the optimal $\mathrm{P}$ status of the soil, the annual fertilisation together with soil $\mathrm{P}$ reserves supply sufficient $\mathrm{P}$ to the crops. The $\mathrm{P}_{\mathrm{Ac}}$ values corresponding to the RCY value of $95 \%$ were considered a relevant target level of $\mathrm{P}$ fertilisation in clay soils, in which the starter effect of placed $\mathrm{P}$ was frequently rather poor (Saarela et al. 2006). In the more capillary silty and sandy soils, the conditions around the fertiliser bands are probably more favourable for an efficient early rooting by the plant. The immediate effect of the P applied by the placement method is therefore better in silty and sandy soils than in clay soils. Even the fertilisers broadcast on the soil are probably utilised more easily 
Saarela, I. et al. Effects of repeated phosphorus fertilisation on field crops: silty and sandy soils

Table 5. Soil test $\mathrm{P}$ values $\left(\mathrm{P}_{\mathrm{Ac}}, \mathrm{mg} \mathrm{dm}^{-3}\right)$ and relative yields (RY) with five $\mathrm{P}$ fertilisation rates during two or three periods at each site and the mean values of two groups of soils with "low" (sites 1-4) and "high" (sites 5-8) initial levels of $\mathrm{P}_{\mathrm{Ac}}$. Parentheses show values with residual $\mathrm{P}$ after withdrawn $\mathrm{P}$ fertilisation. The sufficient rates of $\mathrm{P}$ fertilisation $(\mathrm{kg} / \mathrm{ha})$ and the corresponding soil test $\mathrm{P}$ values that were required for the relative yield of $97 \%$ are given for the entire periods and their subdivisions. The letter (f) indicates means of the final parts.

\begin{tabular}{|c|c|c|c|c|c|c|c|c|c|c|c|c|c|c|c|}
\hline \multirow{2}{*}{$\begin{array}{l}\text { Site } \\
\text { No }\end{array}$} & \multirow{2}{*}{$\begin{array}{l}\text { Crop } \\
\text { years }\end{array}$} & \multicolumn{5}{|c|}{ Soil $\mathrm{P}_{\mathrm{Ac}}$ by $\mathrm{P}$ rates $\left(\mathrm{kg} \mathrm{ha}^{-1} \mathrm{a}^{-1}\right)$} & \multicolumn{5}{|c|}{$\mathrm{RY}(\%)$ by $\mathrm{P}$ rates $\left(\mathrm{kg} \mathrm{ha}^{-1}\right)$} & \multirow{2}{*}{\multicolumn{2}{|c|}{$\begin{array}{l}\text { RY } 100 \% \text { Sign }^{2)} \\
=\mathrm{kg}^{1)} \mathrm{ha}^{-1} \text { effect }\end{array}$}} & \multicolumn{2}{|c|}{ RY $97 \%$ at } \\
\hline & & 0 & 15 & 30 & 45 & 60 & 0 & 15 & 30 & 45 & 60 & & & $\mathrm{P}$ rate & $\mathrm{P}_{\mathrm{Ac}}$ \\
\hline \multirow[t]{4}{*}{9} & $1-6$ & 3.5 & 4.2 & 4.8 & 4.8 & 5.9 & 73 & 89 & 92 & 100 & 100 & 3110 & 5 & 37 & 4.8 \\
\hline & $7-12$ & 2.8 & 4.2 & 5.4 & 7.7 & 9.5 & 52 & 81 & 90 & 99 & 100 & 2850 & 6 & 40 & 6.9 \\
\hline & $13-15$ & 2.4 & 4.2 & (5.3) & 8.1 & (10.0) & 56 & 80 & (69) & 100 & (86) & 3430 & 2 & 42 & 7.7 \\
\hline & $1-15$ & 3.0 & 4.2 & (5.1) & 6.6 & (8.2) & 61 & 84 & (87) & 100 & (97) & 3070 & 13 & 40 & 6.2 \\
\hline \multirow[t]{3}{*}{10} & $1-6$ & 4.0 & 4.2 & 4.4 & 4.9 & 5.3 & 88 & 93 & 101 & 99 & 100 & 4140 & 4 & 22 & 4.3 \\
\hline & $7-12$ & 3.8 & 4.3 & 5.6 & 6.1 & 7.0 & 80 & 95 & 100 & 102 & 100 & 3160 & 5 & 22 & 4.9 \\
\hline & 1-12 & 3.9 & 4.3 & 5.0 & 5.5 & 6.1 & 84 & 94 & 100 & 101 & 100 & 3650 & 9 & 22 & 4.6 \\
\hline \multirow[t]{4}{*}{11} & $1-6$ & 4.7 & 4.8 & 5.2 & 5.8 & 6.5 & 72 & 89 & 95 & 99 & 100 & 3150 & 5 & 38 & 5.5 \\
\hline & $7-12$ & 4.7 & 5.7 & 6.7 & 7.5 & 9.0 & 56 & 84 & 92 & 98 & 100 & 2780 & 6 & 42 & 7.2 \\
\hline & $13-16$ & 4.6 & 5.8 & (6.8) & 8.7 & (9.4) & 28 & 73 & (53) & 100 & (82) & 3090 & 4 & 42 & 8.4 \\
\hline & $1-16$ & 4.7 & 5.4 & (6.3) & 7.1 & (9.0) & 55 & 83 & (83) & 99 & (95) & 3000 & 15 & 41 & 7.0 \\
\hline \multirow[t]{3}{*}{12} & $1-6$ & 7.3 & 6.6 & 8.9 & 8.1 & 8.7 & 84 & 93 & 95 & 98 & 100 & 2840 & 3 & 38 & 8.4 \\
\hline & $7-12$ & 6.5 & 6.5 & 9.9 & 9.4 & 11.8 & 65 & 84 & 93 & 101 & 100 & 2200 & 5 & 36 & 9.7 \\
\hline & $1-12$ & 6.9 & 6.6 & 9.4 & 8.7 & 10.3 & 75 & 88 & 94 & 100 & 100 & 2520 & 8 & 37 & 9.0 \\
\hline \multirow[t]{3}{*}{13} & $1-6$ & 9.1 & 8.9 & 8.9 & 9.7 & 10.1 & 91 & 97 & 97 & 100 & 100 & 3380 & 2 & 22 & 8.9 \\
\hline & $7-9$ & 7.8 & 8.5 & 8.4 & 8.5 & 7.7 & 86 & 95 & 94 & 101 & 100 & 3050 & 2 & 30 & 8.4 \\
\hline & $1-9$ & 8.6 & 8.8 & 8.7 & 9.3 & 9.3 & 89 & 96 & 96 & 100 & 100 & 4850 & 4 & 26 & 8.7 \\
\hline \multirow[t]{3}{*}{14} & $1-6$ & 9.1 & 8.5 & 8.9 & 9.0 & 9.4 & 85 & 93 & 100 & 100 & 100 & 5580 & 4 & 24 & 8.7 \\
\hline & $7-9$ & 6.9 & 8.1 & 8.9 & 9.2 & 10.1 & 69 & 87 & 93 & 99 & 100 & 3690 & 3 & 38 & 9.1 \\
\hline & $1-9$ & 8.4 & 8.4 & 8.9 & 9.1 & & 79 & 91 & 98 & 100 & 100 & 4950 & 7 & 28 & 8.9 \\
\hline 9-14 & 1-18 & 5.5 & 5.9 & (7.0) & 7.5 & (8.5) & 72 & 88 & (95) & 100 & (99) & 3510 & $56 / 73$ & $32 / 35 f$ & 7.4/8.0f \\
\hline \multirow[t]{4}{*}{15} & $1-6$ & 11.8 & 13.3 & 14.7 & 16.7 & 17.6 & 97 & 98 & 100 & 101 & 100 & 10 & 1(1) & 0 & 11.8 \\
\hline & $7-12$ & 9.7 & 13.3 & 15.9 & 20.4 & 23.5 & 89 & 98 & 100 & 101 & 100 & 3690 & 2 & 12 & 12.9 \\
\hline & $13-18$ & 9.1 & 13.9 & (16.8) & 25.2 & (26.1) & 91 & 97 & (97) & 100 & (98) & 4720 & 4 & 15 & 13.9 \\
\hline & 1-18 & 10.2 & 13.5 & (16.7) & 20.7 & (23.9) & 92 & 98 & (99) & 101 & (99) & 3910 & 8 & 12 & 12.9 \\
\hline \multirow[t]{4}{*}{16} & $1-6$ & 12.9 & 15.0 & 17.3 & 14.9 & 15.2 & 90 & 97 & 101 & 99 & 100 & 5170 & 3 & 15 & 15.0 \\
\hline & $7-12$ & 8.5 & 11.6 & 15.2 & 15.2 & 18.0 & 92 & 96 & 103 & 101 & 100 & 4860 & 2 & 18 & 12.0 \\
\hline & $13-16$ & 6.4 & 10.0 & (12.6) & 15.1 & (15.1) & 80 & 92 & (96) & 100 & (100) & 3470 & 2 & 25 & 11.7 \\
\hline & 1-16 & 9.6 & 12.5 & (15.3) & 15.0 & (16.9) & 88 & 95 & (101) & 100 & $(100)$ & 4630 & 7 & 21 & 13.2 \\
\hline \multirow[t]{3}{*}{17} & $1-6$ & 25.9 & 29.3 & 31.9 & 31.0 & 33.4 & 96 & 98 & 99 & 99 & 100 & 2960 & 2 & 8 & 27.2 \\
\hline & $7-12$ & 21.1 & 26.7 & 29.3 & 32.2 & 36.8 & 97 & 98 & 101 & 100 & 100 & 2330 & 0 & 3 & 22.2 \\
\hline & 1-12 & 23.5 & 28.0 & 30.6 & 31.6 & 35.1 & 96 & 98 & 100 & 99 & 100 & 2640 & 2 & 6 & 25.3 \\
\hline \multirow[t]{3}{*}{18} & $1-6$ & 47.1 & 50.7 & 53.4 & 59.6 & 56.7 & 98 & 98 & 100 & 99 & 100 & 4230 & 0 & 0 & 47.1 \\
\hline & $7-12$ & 35.2 & 37.1 & $(41.8)$ & 51.6 & $(49.6)$ & 102 & 100 & (103) & 97 & $(100)$ & 4360 & 1 & 0 & 35.2 \\
\hline & 1-12 & 41.1 & 43.9 & (47.6) & 55.6 & $(53.1)$ & 100 & 100 & (102) & 98 & (100) & 4290 & 1 & $\mathbf{0}$ & 41.1 \\
\hline $15-18$ & $1-18$ & 19.2 & 22.5 & (25.6) & 28.6 & (30.3) & 94 & 97 & (101) & 100 & (100) & 3930 & $18 / 58$ & $10 / 11 f$ & $3.1 / 20.8 f$ \\
\hline \multirow[t]{4}{*}{ 9-18 } & $1-6$ & 13.5 & 14.5 & 15.8 & 16.4 & 16.9 & 87 & 94 & 98 & 99 & 100 & 3920 & $30 / 60$ & $20^{3)}$ & $14.2^{3)}$ \\
\hline & $7-12$ & 11.1 & 13.1 & 15.4 & 17.7 & 19.3 & 79 & 92 & 97 & 100 & 100 & 3450 & $34 / 54$ & $24^{3)}$ & $12.9^{3)}$ \\
\hline & $13-15$ & 6.2 & 9.4 & $(12.6)$ & 15.9 & $(19.1)$ & 68 & 87 & (95) & 100 & $(100)$ & 3360 & $12 / 17$ & $31^{3)}$ & $10.4^{3)}$ \\
\hline & 1-18 & 11.6 & 13.3 & $(15.2)$ & 16.9 & (18.2) & 81 & 92 & (97) & 100 & $(100)$ & 3690 & 74/131 & \multicolumn{2}{|c|}{ 23/25f $13.7 / 13.1 f$} \\
\hline
\end{tabular}

1) One yield unit contain $1 \mathrm{~kg}$ of grain, $0.5 \mathrm{~kg}$ of rapeseed, one grass feed unit which is equivalent to one $\mathrm{kg}$ of barley or 7 $\mathrm{kg}$ of potatoes

2) Number of years with significant effect at $\mathrm{P}=0.05$ (negative effect in parentheses)

${ }^{3)}$ Mean values of the $P$ rates and $P_{A c}$ values required in each experiment, not a function of these values in the same lane 
Vol. 15 (2006): 423-443.

Fig. 5. Dependence of relative control yield (RCY) on extractable soil P. Large markers denote current conventional cultivation methods and mean values of at least nine crop years (Table 5). Small markers represent residual periods or the old or short studies compiled in Table 1.

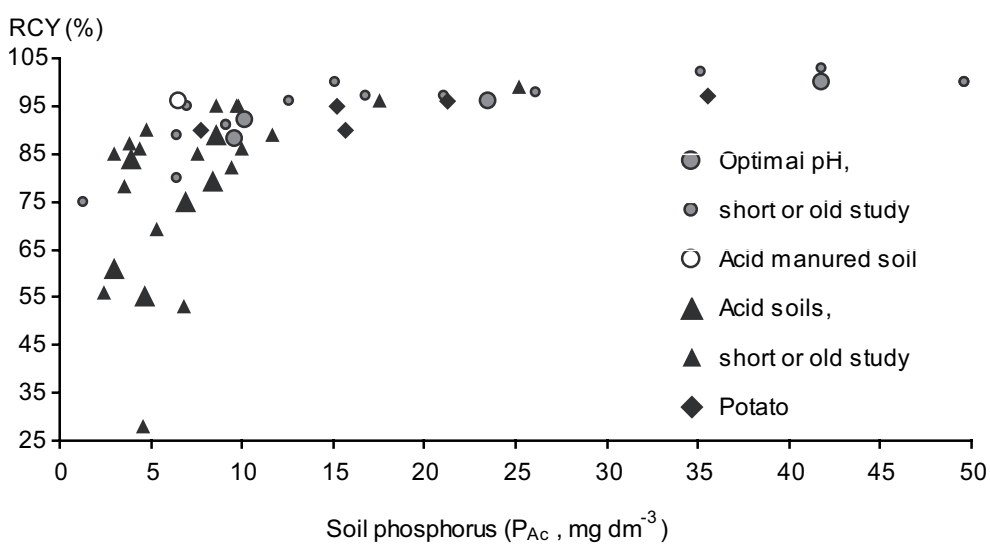

on the moist surface of the capillary soils than on dry surface of clay soils.

The RCY value of $92 \%$ is probably a sufficient target level for the silty and sandy soils annually fertilised with P. Less frequent application of manure would require a slightly better P status. In cereals and leys at an optimal $\mathrm{pH}$, the RCY value of $92 \%$ was reached at the $\mathrm{P}_{\mathrm{Ac}}$ level of 7-10 $\mathrm{mg} \mathrm{dm}^{-3}$ in the short-term studies and at $10-12 \mathrm{mg} \mathrm{dm}^{-3}$ in the longer experiments. A considerably better $\mathrm{P}$ status was required for potatoes. Low and high $\mathrm{P}_{\mathrm{Ac}}$ values predicted the $\mathrm{P}$ fertilisation needs reliably. At a medium level of $\mathrm{P}_{\mathrm{Ac}}$, the optimal value that was sufficient for individual soils depended on other chemical properties and even on the physical characteristics of the soil.

\section{Sufficient $P$ fertilisation and soil $P_{A c}$}

The relationship of the control yields to the soil test $\mathrm{P}$ values as examined by the $\mathrm{RCY} / \mathrm{P}_{\mathrm{Ac}}$ plots defined the sufficient level of $\mathrm{P}$ fertilisation fairly well for the clay and loam soils at optimal $\mathrm{pH}$ (Saarela et al. 2006). Because more $P$ was required and greater yield responses were obtained in silty and sandy soils, the sufficient amounts of P fertilisation can be derived more exactly and reliably from the optimal points of the response curves. In an earlier summary of the results (Saarela et al. 1995), the responses were statistically analysed by multiple regression analysis, and the optimal amounts of $\mathrm{P}$ fertilisation were determined by differential equations for different crops, levels of $\mathrm{P}_{\mathrm{Ac}}$, products per fertiliser price ratios and duration of the experiments. The effects of region, soil type, $\mathrm{pH}$ and content of organic matter were also studied.

In this study, the sufficient rates of $\mathrm{P}$ fertilisation were interpolated from the yields obtained with the five treatments during two or three periods at each site. Because of the five treatments with relatively small differences between the amount of $\mathrm{P}$, the less advanced method gave similar RY values as mathematical functions and is probably fairly reliable in defining the mean amounts of optimal $\mathrm{P}$ fertilisation for the different kinds of soils studied. The approximations are less exact for the individual sites, at least for experiments in which the response curves are flat. The simple calibration can be easily checked without any mathematical expertise.

The rates of $\mathrm{P}$ fertilisation that produced the relative yield of $97 \%$ of the maximum yields obtained with 60 or $45 \mathrm{~kg} \mathrm{P} \mathrm{ha}^{-1}$ were used as the sufficient rates. The relative yield of $97 \%$ is economically close to the optimum in grain and grass production if $10-14 \mathrm{~kg}$ of grain or an equivalent amount of grass is required to pay for one $\mathrm{kg}$ of $\mathrm{P}$, which roughly correspond to the prices of grain and commercial fertilisers in Finland in early 2006. Slightly larger amounts of $\mathrm{P}$ would be profitable 
Saarela, I. et al. Effects of repeated phosphorus fertilisation on field crops: silty and sandy soils

for more valuable crops like table potatoes and in the cycling of domestic $\mathrm{P}$ fertilisers such as animal effluents. For the main original purpose of this project, the determination of what amount of $\mathrm{P}$ fertilisation is sustainable and the most profitable in the long-term, the yield responses and soil-test $\mathrm{P}$ values obtained in the later parts of the study are the most relevant parameters.

The amounts of $\mathrm{P}$ fertilisation and the corresponding soil $\mathrm{P}_{\mathrm{Ac}}$ values that were required to achieve the relative yield of 97\% (RY97) are presented for two or three periods for each site in Table 5. The mean removal of $P$ from the soils in the modest yields was $12.4 \mathrm{~kg} \mathrm{ha}^{-1}$ at the sufficient rate of $\mathrm{P}$ fertilisation. The low and medium initial $\mathrm{P}_{\mathrm{Ac}}$ values of soils 9-15 remained at the initial level with this or a slightly larger amount of applied P, while fertilisation corresponding to roughly three times the removals were required to maintain the higher values of soils 16-18. For RY97, replacement of removed $\mathrm{P}$ sufficed on soil 15 at $\mathrm{P}_{\mathrm{Ac}} 12.9$ $\mathrm{mg} \mathrm{dm}^{-3}$, while little or no $\mathrm{P}$ was required on soils 17 and 18 at $\mathrm{P}_{\mathrm{Ac}} 24.2$ and $41.1 \mathrm{mg} \mathrm{dm}^{-3}$. The initially rich soil 16 , in which the grasses grown for several years caused a mean P removal of $18.5 \mathrm{~kg}$ $\mathrm{ha}^{-1}$, finally required $25 \mathrm{~kg} \mathrm{P} \mathrm{ha}{ }^{-1}$ at $\mathrm{P}_{\mathrm{Ac}} 11.7 \mathrm{mg}$ $\mathrm{dm}^{-3}$. The mean final sufficient $\mathrm{P}$ rate for soils 15-18 was $11 \mathrm{~kg} \mathrm{ha}^{-1}$, and the corresponding mean $\mathrm{P}_{\mathrm{Ac}}$ value was $20.8 \mathrm{mg} \mathrm{dm}^{-3}$.

At least two times the amounts of $\mathrm{P}$ removed by the crops had to be applied for RY97 on the less enriched soils 9-14 (Table 5). The poorest soil, soil 11, required about four times the amount of $\mathrm{P}$ contained by the modest yields. During the final period, a $\mathrm{P}$ rate of $40 \mathrm{~kg} \mathrm{ha}^{-1}$ was required on most soils of this group. Lower P rates sufficed for timothy on soil 13, which had a high content of organic matter, and on soil 10, which suffered from detrimental lodging. The mean sufficient amount of P fertilisation for soils 9-14 was $35 \mathrm{~kg}$ $\mathrm{ha}^{-1}$ for the final period, and the corresponding $\mathrm{P}_{\mathrm{Ac}}$ value was $8.0 \mathrm{mg} \mathrm{dm}^{-3}$. The mean sufficient rates of $\mathrm{P}$ fertilisation changed little with time, while the relative yields obtained with the treatment 15 $\mathrm{kg} \mathrm{P} \mathrm{ha}{ }^{-1}$ declined steeply on soils $11,12,14$ and 16. A corresponding decline in the $\mathrm{P}_{\mathrm{Ac}}$ values was measured only for soil 16 , in which the initial value was high and the soil $\mathrm{pH}$ decreased with time.

\section{Chemical reasons for the poor availability of soil $P$}

Well-sorted sandy soils, in which aluminium is the main sorption agent (Kaila 1963), tend to have lower concentrations of water extractable $\mathrm{P}$ in relation to $\mathrm{P}_{\mathrm{Ac}}$ than fine-textured soils. This relationship, which is the most obvious at low $\mathrm{P}_{\mathrm{Ac}}$ (Saarela 1992a, Saarela et al. 2003), explains the large requirements of $\mathrm{P}$ fertilisation in the coarse-textured mineral soils of the inland regions. The concentrated and acid acetate $(0.5 \mathrm{M}$ acetate, $0.5 \mathrm{M}$ acid, $\mathrm{pH}$ 4.65) dissolves rather large amounts of nonexchangeable aluminium from acid soils (Mäkitie 1968) and probably releases irreversibly sorbed phosphate. The Morgan method similar to the Finnish acetate method was a good indicator of the availability of recently applied P in some American soils (Kuo 1990), but a much longer contact time of the applied $\mathrm{P}$ to the treated soil or other possible reasons caused more divergent relationships in our study. As theoretically shown by van Noordwijk et al. (1990), the physical properties of sandy soils may also weaken the supply of $\mathrm{P}$ to crops at the same $\mathrm{P}_{\mathrm{w}}$.

The soils that had very low $\mathrm{P}_{\mathrm{w}}$ values and appeared biologically deficient in $\mathrm{P}$ contained rather large amounts of secondary inorganic $\mathrm{P}$ reserves (Saarela et al. 2003), of which the major part was extractable by ammonium fluoride (Hartikainen 1989). The amounts of $P$ extracted from these soils by the Olsen, lactate and resin methods (Table 2) are also relatively large. Only the resin method and the milder extraction agents or intensity tests agreed with the yield responses obtained on soils 14 and 15 . In this study the Olsen method was an unreliable indicator of the need for P fertilisation. However, the poor availability of the large apatitic pool in soil 15 (Hartikainen 1989, Saarela et al. 2003) and the better available sizeable residuals in soil 18 were correctly predicted by all methods. 
Vol. 15 (2006): 423-443.

The poor availability of $\mathrm{P}$ in the problem soils that contained large amounts of labile secondary phosphates was probably related to the high concentrations of sorption active aluminium (Hartikainen 1989). The detrimental effect of aluminium was demonstrated also by high values of the sorption indexes based on the contact time of one week (Saarela et al. 2003). The P saturation index (PSI) was low and varied little between the 16 soils of this project analysed for the inorganic $\mathrm{P}$ fractions and oxalate extractable aluminium and iron (Hartikainen 1989).

The relationships of $\mathrm{P}_{\mathrm{Ac}}$ and water extractable $\mathrm{P}$ $\left(\mathrm{P}_{\mathrm{w}}\right)$ and PSI were curvilinear (Saarela et al. 2003), and both test values increased steeply with PSI from the medium level. $\mathrm{P}_{\mathrm{Ac}}$ was 3.9 and $\mathrm{P}_{\mathrm{w}} 2.4 \mathrm{mg} \mathrm{dm}^{-3}$ at PSI 5\%, and $\mathrm{P}_{\mathrm{Ac}}$ was 16.9 and $\mathrm{P}_{\mathrm{w}} 17.5 \mathrm{mg} \mathrm{dm}^{-3}$ at PSI $12 \%$. The low $\mathrm{P}_{\mathrm{w}}$ values at the low and medium level of PSI agreed with the review by Vadas et al. (2005), in which the relationship between the concentration of dissolved reactive $\mathrm{P}$ in runoff (DRP) and the PSI values was calculated by using a large number of samples compiled from several studies. DRP was very low up to the PSI value of $8.8 \%$ and increased sharply with higher values.

The soils that had relatively high $\mathrm{P}_{\mathrm{w}}$ values and supplied more $\mathrm{P}$ to plants had lower concentrations of oxalate extractable aluminium but similar or higher concentrations of oxalate extractable iron (Hartikainen 1989). According to Kaila (1963), a high concentration of sorption active aluminium in relation to iron is typical of coarse-textured soils, while a high concentration of sorption active iron is typical of fine-textured soils. However, the variation between individual soils is large. Among the 74 mineral soils collected from different parts of all Finland and studied by Yli-Halla (1993), some very coarse-textured soils, mainly sandy moraines, had much more oxalate extractable iron than aluminium. Acid acetate solutions dissolve large amounts of non-exchangeable aluminium from acid soils (Mäkitie 1968), which is probably a major reason for the poorer supply of $\mathrm{P}$ to crops in coarse-textured than in fine-textured soils at the same $\mathrm{P}_{\mathrm{Ac}}$.

The generally low $P_{w}$ values in relation to the $\mathrm{P}_{\mathrm{Ac}}$ values of coarse-textured Finnish soils were discovered by Sippola and Jansson (1979); the mean $\mathrm{P}_{\mathrm{w}}$ value of 123 different coarse mineral soils, $3.8 \mathrm{mg} \mathrm{dm}^{-3}$, was $45 \%$ of the mean $\mathrm{P}_{\mathrm{Ac}}$ value for the same soils, $8.5 \mathrm{mg} \mathrm{dm}^{-3}$, while the mean $\mathrm{P}_{\mathrm{w}}$ of 51 clay soils, $5.1 \mathrm{mg} \mathrm{dm}^{-3}$, was $74 \%$ of the mean $\mathrm{P}_{\mathrm{Ac}}, 6.9 \mathrm{mg} \mathrm{dm}^{-3}$. The concentration of $\mathrm{P}$ in soil solution or the intensity of $\mathrm{P}$ is a critical factor for the supply of $\mathrm{P}$ to crops in Finnish mineral soils (Saarela 1992a). Comparisons of several chemical methods have shown that the $\mathrm{P}_{w}$ values and other reliable intensity tests predict the $\mathrm{P}$ fertilisation needs more accurately for mineral soils than the $\mathrm{P}_{\mathrm{Ac}}$ values (Aura 1978, Yli-Halla 1990, Saarela 1992a, Saarela et al. 1996).

The water extraction method that is carried out for P testing only is generally considered unsuitable for routine soil analysis, but its advantages could be probably applied by a modified acetate method. The amounts of aluminium extracted in acetate solutions varying in $\mathrm{pH}$ decreased steeply with acidity (Mäkitie 1968). The amounts of $\mathrm{P}$ extracted from mineral soils also decreased with acidity, but less steeply (Mäkitie 1956). A slightly larger volume (about double) of a less acid acetate solution ( $\mathrm{pH}$ about 5.3) would extract similar average amounts of $\mathrm{P}$ to those of the present procedure. The $\mathrm{P}_{\mathrm{Ac}}$ values determined by the modified method would obviously deviate less from the more reliable $\mathrm{P}_{\mathrm{w}}$ values and indicate the requirements for $\mathrm{P}$ fertilisation better for different types of soil as well as for individual soils.

An additional chemical characteristic that was measured in the most responsive soils was a low concentration of extractable calcium or soil test $\mathrm{Ca}$ value, which in the plough layer is typically about $1000 \mathrm{mg} \mathrm{dm}^{-3}$ for sandy loam soils and slightly higher for silt loams. In soil 11 , the Ca value was $280 \mathrm{mg} \mathrm{dm}^{-3}$ (initially before liming, final 590-740 $\mathrm{mg} \mathrm{dm}^{-3}$ with $0-45 \mathrm{~kg} \mathrm{P} \mathrm{ha}^{-1}$ ) and at least $700 \mathrm{mg}$ $\mathrm{dm}^{-3}$ in other sandy soils (Saarela et al. 2003). In the subsoil layer the $\mathrm{Ca}$ value was as low as $50 \mathrm{mg}$ $\mathrm{dm}^{-3}$ in the acid loamy sand 14 (pH 5.2 in subsoil and 5.8 in topsoil), $110 \mathrm{mg} \mathrm{dm}^{-3}$ in soil $11,220 \mathrm{mg}$ $\mathrm{dm}^{-3}$ in soil $10,240 \mathrm{mg} \mathrm{dm}^{-3}$ in soil 18 , and at least $1000 \mathrm{mg} \mathrm{dm}^{-3}$ in the silty soils, excluding the strongly acid sulfic soil 13 . 
Saarela, I. et al. Effects of repeated phosphorus fertilisation on field crops: silty and sandy soils

Together with the low $\mathrm{pH}$ values causing high concentrations of mobile aluminium, the lowest Ca values are probably insufficient for good root growth and nutrient uptake. The concentration of $\mathrm{Ca}$ in the extraction solution, which defines soil test $\mathrm{Ca}$ values, may also affect the equilibrium concentration of phosphate in the solution and thereby the resulting $\mathrm{P}_{\mathrm{Ac}}$ values. The role of $\mathrm{Ca}$ in the utilisation of soil $\mathrm{P}$ reserves would need additional studies. Soil test $\mathrm{Ca}$, or the sum of macrocations (Saarela et al. 2003) that are measured in every soil sample in routine soil testing, would be a feasible parameter for calibrating the $\mathrm{P}_{\mathrm{Ac}}$ values more precisely for different types of soil.

\section{Conclusions}

The silty and sandy soils that mainly occur in the inland regions of Finland required larger amounts of $\mathrm{P}$ fertilisation than the southern and western clay and loam soils. The optimum $\mathrm{P}_{\mathrm{Ac}}$ value of silty and sandy soils was not very exactly defined, but it was certainly considerably higher than what is sufficient in clay and loam soils. On the basis of the relative control yield of $92 \%$ at optimal $\mathrm{pH}$, the sufficient $\mathrm{P}_{\mathrm{Ac}}$ value of silty and sandy soils was typically $10-12 \mathrm{mg} \mathrm{dm}^{-3}$ for cereals and leys, and significantly higher for potato.

The amounts of $\mathrm{P}$ fertilisation required on the soils were determined on the basis of the relative yield of $97 \%$ of the maximum. The $\mathrm{P}$ rates were interpolated from the yields obtained with five different amounts of $\mathrm{P}$ and related to the corresponding soil $\mathrm{P}_{\mathrm{Ac}}$ values. In the later part of the study, the mean requirement of the six soils that had low or medium $\mathrm{P}_{\mathrm{Ac}}$ values was $35 \mathrm{~kg} \mathrm{P} \mathrm{ha}^{-1}$, and the corresponding soil $\mathrm{P}_{\mathrm{Ac}}$ value was $8.0 \mathrm{mg} \mathrm{dm}^{-3}$. On the four soils that had higher $\mathrm{P}_{\mathrm{Ac}}$ values, the mean requirement was $11 \mathrm{~kg} \mathrm{P} \mathrm{ha}^{-1}$, and the corresponding $\mathrm{P}_{\mathrm{Ac}}$ value was $20.8 \mathrm{mg} \mathrm{dm}^{-3}$. The mean requirement of the ten silty and sandy soils was $25 \mathrm{~kg} \mathrm{P} \mathrm{ha}^{-1}$, and the corresponding $\mathrm{P}_{\mathrm{Ac}}$ value $13.1 \mathrm{mg} \mathrm{dm}^{-3}$, which is similar to the mean value of Finnish soils. All the soils contained typical amounts of residual fertiliser P and were not selected as specially P requiring sites.

The amounts of annual P fertilisation that produced optimal yields on the less fertile soils are larger than allowed by the Finnish Agri-Environmental Program, while the agronomic and environmental requirements were close to each other on the more enriched soils, which were also less acid. The soils that required high $P$ rates had been enriched with relatively large amounts of applied $\mathrm{P}$, but its supply to crops was impaired by chemical and physical factors. Moderate acidity and high concentration of sorption active aluminium decreased the concentration of $\mathrm{P}$ in soil solution, and the poor structure of silty soils restricted $\mathrm{P}$ uptake physically. The supply of $\mathrm{P}$ to crops in acid silty and sandy soils can be improved by liming, but the $\mathrm{P}$ fertilisation needs do not necessarily decrease in relation to the soil-test $\mathrm{P}$ values, because the $\mathrm{P}_{\mathrm{Ac}}$ values also increase with $\mathrm{pH}$ and diminish the amounts of $\mathrm{P}$ fertilisation based on this soil test.

Acknowledgements. This research project was initiated by the late Professor Paavo Elonen and conducted at the Soils and Environment unit in Jokioinen and at MTT's seven research stations by local staff under local direction. The authors wish to thank all the colleagues who contributed to the field and laboratory studies and preparation of this paper. Appreciation is owed to Sten Engblom, SLU, Sweden, Leo Kevvai, ERIA, Estonia, Bernardo van Raij, IA, Brazil, Sjoerd van der Zee, WAU, the Netherlands, and Pekka Kivistö, MTT, Finland, for soil analyses, Risto Tanni and Matti Ylösmäki for performing field experiments and Kerttu Hämäläinen and Katariina Saarela for handling and analysing yields.

\section{References}

Aura, E. 1978. Determination of available soil phosphorus by chemical methods. Journal of the Scientific Agricultural Society of Finland 50: 305-316.

Dodd, J.R. \& Mallarino, A.P. 2005. Soil-test phosphorus and crop yield responses to long-term phosphorus fertilisation for corn-soybean rotations. Soil Science Society of America Journal 69: 1118-1128.

Egnér, H., Riehm, H. \& Domingo, W. H. 1960. Untersuchungen über die chemische Bodenanalyse als Grundlage 
Vol. 15 (2006): 423-443.

für die Beurteilung des Nährstoffzustands der Böden. II. Chemische Extraktionsmethoden zur Phosphor- und Kaliumbestimmung. Kungliga Lantbrukshögskolans Annaler 26: 199-215.

Elonen, P. 1971. Particle-size analysis of soil. Acta Agralia Fennica 122: 1-122.

Hakkola, H. 1998. Annual and storage application of phosphorus to ley. Kungliga Skogs- och Lantbruksakademiens Tidskrift 137: 99-104.

Hartikainen, H. 1989. Effect of cumulative fertilizer dressings on the phosphorus status of mineral soils. Journal of Agricultural Science in Finland 61: 55-66.

Herlihy, M., McCarthy, J. \& Brennan, D. 2006. Divergent relationships of phosphorus soil tests in temperate grassland soils. Communications in Soil Science and Plant Analysis 37: 693-715.

Houba, V.J.G., Novozamsky, I., Lexmond, T.M. \& van der Lee, J.J. 1990. Applicability of the $0.01 \mathrm{M} \mathrm{CaCl}_{2}$ as a single extractantion solution for the assessment of the nutrient status of soils and other diagnostic purposes. Communications in Soil Science and Plant Analysis 21: 2281-2290.

Jaakkola, A., Hakkola, H. Köylijärvi, J. \& Simojoki, P. 1977. Effect of liming on phosphorus fertilizer requirement in cereals and ley. Annales Agriculturae Fenniae 16: 207-219.

Jaakkola, A., Hartikainen, H. \& Lemola, R. 1997. Effect of fertilization on soil phosphorus in a long-term field experiment in Southern Finland. Agricultural and Food Science in Finland 6: 313-322.

Kähäri, J., Mäntylahti, V. \& Rannikko, M. 1987. Suomen peltojen viljavuus 1981-1985. Summary: Soil fertility of Finnish cultivated soils in 1981-1985. Viljavuuspalvelu Oy. 105 p.

Kahiluoto, H., Ketoja, E., Vestberg, M. \& Saarela, I. 2001. Promotion of AM utilization through reduced $P$ fertilization. 2. Field studies. Plant and Soil 231: 65-79.

Kaila, A. 1963. Dependence of the phosphate sorption capacity on the aluminium and iron in Finnish soils. The Journal of the Scientific Agricultural Society of Finland 35: 165-177.

Ketterings, O.M., Czymmek, K.J., Reid, W.S. \& Wildman, R.F. 2002. Conversion of modified Morgan and Mehlich-III soil tests to Morgan soil test values. Soil Science 167: 830-837.

Kuo, S. 1990. Phosphate sorption implications on phosphate soils tests and uptake by corn. Soil Science Society of America Journal 54: 131-135.

Kurki, M. 1982. Suomen peltojen viljavuudesta III. Summary: On the fertility of Finnish tilled fields III. Viljavuuspalvely Oy, Helsinki 1982. $181 \mathrm{p}$.

Lakanen, E. \& Vuorinen, J. 1963. The effect of liming on the solubility of nutrients in various Finnish soils. Annales Agriculturae Fenniae 2: 91-102.

Luostarinen, H. 1967. Vaaramoreenin lannoitus- ja kalkituskokeen tuloksia. Summary: Results from a fertilizing and liming test on hill moraine. Journal of the Scientific Agricultural Society of Finland 39: 191-204.

Mäkitie, O. 1956. Uuttamisesta viljavuustutkimuksessa. Summary: Studies on the acid ammonium acetate extraction method in soil testing. Agrogeological Publications 66. $25 \mathrm{p}$.
Mäkitie, O. 1968. Aluminium, extractable from soil samples by the acid ammonium acetate soil-testing method. Journal of the Scientific Agricultural Society of Finland 40: 54-59.

Munk, H. \& Rex, M. 1990. Zur Eichung von Bodenuntersuchungsmethoden auf Phosphat. Summary: Notes on the calibration of phosphate soil testing methods. Agrobiological Research 43: 164-174.

Munk, H., Heyn, J. \& Rex, M. 2005. Vergleichende Betrachtung von Verfahren zur Auswertung von Nährstoffsteigerungsversuchen am Beispiel Phosphor. Summary: Comparison of two procedures to evaluate phosphatefertilizing field trials. Journal of Plant Nutrition and Soil Science 168: 789-796.

Noordwijk, M. van, Willigen, P. de, Ehlert, P.A.J. \& Chardon, W.J. 1990. A simple model of $P$ uptake by crops as a possible basis for $\mathrm{P}$ fertiliser recommendations. $\mathrm{Ne}$ therlands Journal of Agricultural Sciences 38: 317-332.

Raij, B. van 1998. Bioavailable tests: Alternatives to standard soil extractions. Communications in Soil Science and Plant Analysis 29: 1553-1570.

Saarela, I. 1992a. A simple diffusion test for soil phosphorus availability. Plant and Soil 147: 115-126.

Saarela, I. 1992b. Agronomic efficiency and environmental effects of large doses of phosphorus with establishment vs. annual topdressing in leys. Proceedings of the 14th General Meeting of the European Grassland Federation, Lahti, Finland, June 8-11 1992. p. 528-530.

Saarela, I. 2002. Phosphorus in Finnish soils in the 1900s with particular reference to the acid ammonium acetate soil test. Agricultural and Food Science in Finland 11: 257-271.

Saarela, I. \& Elonen, P. 1982. Fosforilannoituksen porraskokeet 1977-1981 (Experiments on different rates of phosphorus fertilisation, 1977-1981). Maatalouden tutkimuskeskus, Maanviljelyskemian ja -fysiikan laitos, Tiedote $16.55 \mathrm{p}$.

Saarela, I., Engblom, S., Kevvai, L., van Raij, B., Sippola, J. \& van der Zee, S. 1996. Present soil testing methods and new nutrient separation techniques as predictors of the responses of field crop yields to phosphorus fertilisation in Finland. Helsinki: Agro-food ry. p. P7. (In Finnish, the original English poster text available at MTT Agrifood Research Finland, Soils and Environment, Fl-31600 Jokioinen, Finland).

Saarela, I., Järvi, A., Hakkola, H. \& Rinne, K. 1995. Fosforilannoituksen porraskokeet 1977-1994. Summary: Phosphorus fertilizer rate trials, 1977-1994. Maatalouden Tutkimuskeskus, Tiedote 16/95. 94 p. + 14 app.

Saarela, I., Järvi, A., Hakkola, H. \& Rinne, K. 2003. Phosphorus status of diverse soils in Finland as influenced by long-term $P$ fertilisation. 1. Native and previously applied P at 24 experimental sites. Agricultural and Food Science in Finland 12: 117-132.

Saarela, I., Järvi, A., Hakkola, H. \& Rinne, K. 2004. Phosphorus status of diverse soils in Finland as influenced by long-term $P$ fertilisation. 2. Changes of soil test values in relation to $\mathrm{P}$ balance with references to incorporation depth of residual and freshly applied P. Agricultural and Food Science in Finland 13: 276-294.

Saarela, I., Salo, Y. \& Vuorinen, M. 2006. Effects of repeated phosphorus fertilisation on field crops in Finland 1. 


\section{AGRICULTURAL AND FOOD SCIENCE}

Saarela, I. et al. Effects of repeated phosphorus fertilisation on field crops: silty and sandy soils

Yield responses in clay and loam soils in relation to soil test $\mathrm{P}$ values. Agricultural and Food Science 15: 106-123.

Salonen, M. \& Tainio, A. 1956. Savimaan lannoitusta koskevia tutkimuksia. Summary: Investigations concerning the manuring and fertilizing of clay soils. Publications of the Finnish State Agricultural Research Board 146. $86 \mathrm{p}$.

Salonen, M. \& Tainio, A. 1957. Fosforilannoitusta koskevia tutkimuksia. Summary: Results of field experiments with different amounts of phosphate fertilizers. Publications of the Finnish State Agricultural Research Board 164. $104 \mathrm{p}$.

Schachtschabel, P. 1973. Beziehung zwischen den Phosphorgehalt in Böden und jungen Haferpflanzen. Summary: Relationship between $\mathrm{P}$ content of soils and young oat plants. Journal of Plant Nutrition and Soil Science 135: 31-43.

Sibbesen, E. \& Sharpley, A.N. 1997. Setting and justifying upper critical limits for phosphorus in soils. In: Phosphorus loss from soils to water. CAB International, Wallingford. p. 151-176.

Sippola, J. 1974. Mineral composition and its relation to texture and to some chemical properties in Finnish subsoils. Annales Agriculturae Fenniae 13: 169-234.

Sippola, J. 1980. The dependence of yield increases obtained with phosphorus and potassium fertilization on soil test values and soil pH. Annales Agriculturae Fenniae 19: 100-107.

Sippola, J. \& Jansson, H. 1979. Soil phosphorus test values obtained by acid ammonium acetate, water and resin extraction as predictors of phosphorus content in timothy (Phleum pratense L.). Annales Agriculturae Fenniae 18: 225-230.
Syvälahti, J. 1970. Kauran lannoituksesta. Uudisviljelykokeiden tuloksia vuosilta 1947-61. Summary: Fertilization of oats. Results of experiment on clearings in 1947-61. Annales Agriculturae Fenniae 9: 107-126.

Tähtinen, H. 1977. The effect of sulphur on the yield and chemical composition of timothy. Annales Agriculturae Fenniae 16: 220-226.

Vadas, P.A., Kleinman, P.J.A., Sharpley, A.N. \& Turner, B.L. 2005. Relating soil phosphorus to dissolved phosphorus in runoff: A single extraction coefficient for water quality modeling. Journal of Environmental Quality 34: 572-580.

Varis, E. 1972. The effects of increasing NPK rates on the yield and quality of the Pito potato. I. Tuber yield, starch content and starch yield. Acta Agralia Fennica 128, 1: $1-20$.

Vaishvila, Z., Matusevichius, K. \& Mazhvila, J. 2000. Amount of phosphorus in the soils of Lithuania and its role in optimization of agricultural crops nutrition. Potassium and Phosphorus: fertilisation effect on soil and crops. Proceedings of the Regional IPI Workshop, October 23-24, 2000 Lithuania. p. 85-91.

Vuorinen, J. 1952. Koetilojen peltojen viljavuudesta. Summary: On the fertility of soils on experimental farms in Finland. Agrogeological Publications 59. 59 p. + app.

Vuorinen, $\mathrm{J}$ \& Mäkitie, O. 1955. The method of soil testing in use in Finland. Agrogeological Publications 63. 44 p.

Yli-Halla, M. 1990. Comparison of a bioassay and three chemical methods for determination of plant-available $P$ in cultivated soils in Finland. Journal of Agricultural Science in Finland 62: 213-219.

Yli-Halla, M. 1993. Plant-availability of soil and fertilizer zinc in cultivated soils in Finland. Agricultural Science in Finland 2: 197-270. 


\section{SELOSTUS}

\section{Vuosittain toistetun fosforilannoituksen vaikutus Suomen peltokasvien satoon \\ 2. Hiesu- ja hietamaiden fosforintarve}

Into Saarela, Harri Huhta ja Perttu Virkajärvi

MTT Kasvintuotannon tutkimus

Sisämaassa yleisistä hiesuisista ja karkeista maista kasvit saavat fosforia vähemmän kuin etelä- ja länsirannikon savi- ja hiuemaista. Hiesu- ja hietamaiden fosforilannoituksen tarvetta tutkittiin kymmenellä 9-18-vuotisella kenttäkokeella, joissa verrattiin viiden vuosittain annetun fosforimäärän vaikutuksia kaikkiaan 131 koesadon perusteella. Useimmissa kokeissa viljeltiin viljaa, joissakin nurmea ja yhdessä kokeessa perunaa. Tutkittaessa lannoituksen vaikutusta suhteessa asetaattimenetelmällä määritettyyn maan P-lukuun käytettiin lisäksi aikaisempien tutkimusten tuloksia kahdeksaltatoista koepaikalta.

Fosforilannoitus lisäsi satoa kaikilla niillä mailla, joiden P-luku oli alhainen tai keskinkertainen, ja perunan satoa myös melko runsasfosforisilla mailla. Ilman fosforilannoitusta saatu suhteellinen sato prosentteina riittävällä fosforilannoituksella saadusta sadosta oli kymmenessä kokeessa keskimäärin $81 \%$ (vastaava maan P-luku 11,6 mg/ $/ \mathrm{dm}^{3}$ ) vaihdellen $55 \%$ :sta maan Pluvulla $4,7 \mathrm{mg} / \mathrm{dm}^{3} 100 \%$ :iin P-luvulla $35,2 \mathrm{mg} / \mathrm{dm}^{3}$. Nykyisillä hintasuhteilla pitkänä aikana optimaaliseksi arvioidun $97 \%$ :n suhteellisen sadon perusteella koekauden lopussa tarvittiin fosforia keskimäärin $25 \mathrm{~kg} / \mathrm{ha}$ (vaihtelu 0-42 kg/ha). Kuudella niukka- ja keskifosforisella maalla (P-luku 4,5-9,1 mg/dm ${ }^{3}$, keskimäärin 8,0 $\mathrm{mg} / \mathrm{dm}^{3}$ ) tarvittiin fosforia $35 \mathrm{~kg} / \mathrm{ha}$ (vaihtelu 20-42 $\mathrm{kg} / \mathrm{ha}$ ), kun taas $10 \mathrm{~kg} / \mathrm{ha} \mathrm{P}$ (vaihtelu $0-25 \mathrm{~kg} / \mathrm{ha}$ ) riitti neljällä runsasfosforisemmalla maalla (P-luku keskimäärin $20,8 \mathrm{mg} / \mathrm{dm}^{3}$, vaihtelu $13,0-35,2 \mathrm{mg} / \mathrm{dm}^{3}$ ). Niukkafosforisilla mailla fosforin tarve oli jonkin verran suurempi kuin nykyisten ympäristötuen ehtojen mukaan voidaan käyttää.

Happamien hiesu- ja hietamaiden suurta fosforilannoituksen tarvetta voidaan vähentää kalkituksella. Vahvasti happamilla mailla fosforivarojen hyödyntämisen tehostuminen johtuu paljolti paremmasta juurten kasvusta ja ravinteiden otosta maan P-luvun ollessa sama. Lievästi happamien karkeiden maiden fosforilannoituksen tarve ei välttämättä pienene kalkituksella lainkaan kemiallisesti arvioituun lannoitustarpeeseen verrattuna, koska pH:n noustessa myös maan P-luku suurenee ja siihen perustuva fosforilannoitus pienenee. 